\title{
Singles in the city: Happily ever after?
}

\section{Bernhard Riederer $^{1,2, *}$, Nina-Sophie Fritsch ${ }^{3,4}$ and Lena Seewann ${ }^{4}$}

\begin{abstract}
More people than ever are living in cities, and in these cities, more and more people are living alone. Using the example of Vienna, this paper investigates the subjective well-being of single households in the city. Previous research has identified positive and negative aspects of living alone (e.g., increased freedom vs. missing social embeddedness). We compare single households with other household types using data from the Viennese Quality of Life Survey (1995-2018). In our analysis, we consider overall life satisfaction as well as selected dimensions of subjective wellbeing (i.e., housing, financial situation, main activity, family, social contacts, leisure time). Our findings show that the subjective well-being of single households in Vienna is high and quite stable over time. While single households are found to have lower life satisfaction than two-adult households, this result is mainly explained by singles reporting lower satisfaction with family life. Compared to households with children, singles are more satisfied with their financial situation, leisure time and housing, which helps to offset the negative consequences of missing family ties (in particular with regard to single parents).
\end{abstract}

Keywords: singles; city; Vienna; subjective well-being; comparison of household types

\section{Introduction}

In recent decades, Western societies have undergone a huge transformation in family and household structures, which has been partly caused by fundamental

\footnotetext{
${ }^{1}$ Vienna Institute of Demography (OeAW), Wittgenstein Centre for Demography and Global Human Capital (IIASA, OeAW, University of Vienna), Austria

${ }^{2}$ Institute for Sociology, University of Vienna, Austria

${ }^{3}$ Institute for Sociology and Social Research, Vienna University of Economics and Business, Austria

${ }^{4}$ Department of Sociology, University of Potsdam, Germany

*Correspondence to: Bernhard Riederer, bernhard.riederer@oeaw.ac.at and bernhard.riederer@ univie.ac.at
} 
changes in norms and values (Hettlage 2000; Lesthaeghe 2010; Van de Kaa 1987). Individualisation and the deinstitutionalisation of the nuclear family (Bengtson 2001; Cherlin 2004) have led to a rising variety of household arrangements and a proliferation of alternative living arrangements (Buzar et al. 2005; Friedlander et al. 1999; Kuijsten 1995). In particular, the share of people living alone has increased sharply in Western industrialised countries (Chandler et al. 2004). In response to these developments, social scientific research has shown that so-called 'singles' have gained in societal relevance (Hradil 1995; Poortman and Liefbroer 2010). The term 'single' is usually defined in reference to a person's living arrangement and/or relationship status (see Hertel et al. 2007). In the present article, however, we mainly refer to single households (i.e., individuals living alone). Recent research has described the new trend towards living alone as a personal lifestyle that people choose, rather than as the result of a lack of alternatives (Hertel et al. 2007). This new way of life has become increasingly common in part because of more liberal attitudes towards people living alone, and in part because people have an increasing economic ability to do so (Ogden and Hall 2000). Mass urbanisation has also provided the conditions for the rise of single households, because it has led to the emergence of booming subcultures of singles, and of an infrastructure that supports their lifestyles (Klinenberg 2012). Today, single households seem to be predominantly a phenomenon of urban metropolitan regions, where people who live alone cluster together in specific areas (Bertram 1993, p. 4; Klinenberg 2012). Accordingly, the increase in single households has been most pronounced in global cities like Paris, London and New York (Buzar et al. 2005; Hall and Ogden 2003; Hall et al. 1997). Thus, 'living alone' is mainly a feature of urban life (Bennett and Dixon 2006; Chandler et al. 2004).

Against this background, the present paper addresses the subjective well-being of single households in the city. Previous research on quality of life has repeatedly shown that family status is among the most relevant predictors of subjective well-being (Frey and Stutzer 2002; Haller and Hadler 2006; Layard 2005; Riederer 2018). Within this research tradition, a plethora of studies have analysed the extent to which marital status or living arrangements influence life satisfaction or happiness (e.g. Blekesaune 2018; Chang 2013; Mastekaasa 1994; Soons and Kalmijn 2009; Vanassche et al. 2013). However, there is little quantitative research on subjective well-being that has focused explicitly on the well-being of those who live alone (exceptions are, for example, Luhmann and Hawkley 2016; Soons and Liefbroer 2008). Broadening our perspective, we assume that life satisfaction and happiness are affected not just by family ties, but also by developments in many other areas of life. While quality of life research indicates that not being in an intimate relationship is associated with lower well-being among people who are living alone, research on social change has emphasised that having personal freedom (including gains in independence and leisure time) enables single people to develop new lifestyles, and thus positively influences their levels of well-being. Hence, the question of whether the subjective well-being of single households is lower overall is anything but trivial. The answer to this question would likely be interesting not only for quality of life researchers and family scientists, but 
also for demographers and urbanologists, as many cities are increasingly affected by both the prevalence of smaller households and issues of urban quality of life (Brown et al. 2016; Hogan et al. 2016; Krekel et al. 2016; Marans 2012). Against this background, we aim to answer the following research questions: Are people who live alone more or less satisfied with their lives than others? Which specific domains of subjective well-being are relevant to explain the revealed differences in life satisfaction between household types? And, which factors contribute to the differences in well-being domains between household types?

Our comparative analysis of the well-being of single households contributes to the state of research in various ways. Going beyond previous studies, we include in our analysis different domains of subjective well-being (i.e., housing, financial situation, main activity, family, social contacts, leisure time) in order to disentangle the broad concept of quality of life, rather than examining a concept that is operationalised through a single question (Vanassche et al. 2013). This approach allows us to determine which 'components' of well-being contribute the most to the differences observed between single households and other household types. Moreover, our study adds to research on quality of life in metropolitan regions. Although there is a large body of existing research in this area, ${ }^{1}$ there has been, to our knowledge, no systematic study of the subjective quality of life of singles in the urban context, as most of this previous research focused on specific groups and topics (e.g., the elderly in modern smart, digital, e-participating cities). Using the example of Vienna, the present study aims to help fill this research gap. To do so, we analyse a unique dataset, the Viennese Quality of Life Survey (total $N=41,920$ ), which covers almost a quarter of a century (1995-2018). Our analyses are of descriptive nature due to the cross-sectional character of the data on the individual level. Nevertheless, we perform a series of regression and decomposition analyses in order to shed light on how specific life domains influence the differences in overall life satisfaction between household types, and to explore the reasons why these differences exist.

The city of Vienna is an interesting case to study. First, the composition of Viennese households clearly demonstrates that singles are an urban phenomenon. Of the private households in Vienna, more than 400,000, or 44 per cent, are single households. Figure 1 illustrates the significant growth of single households since 1971 in Vienna, and in Austria as a whole. Today, 22 per cent of Viennese residents and 17 per cent of Austrian residents live in single households (Statistics Austria 2020). Second, compared to other European cities, Vienna has a similar or even

\footnotetext{
1 Studies on quality of life in metropolitan areas can be largely assigned to three main thematic areas: (a) studies emphasising changes in population composition, i.e., demographic rejuvenation and the ageing of cities (Bouzarovski et al. 2010, p. 214); (b) quality of urban life studies that refer to perceptions of the residential environment, e.g., satisfaction with housing or leisure activities (Marans 2012; Marans and Stimson 2011; Weziak-Bialowolska 2016) and their interrelationship with overall quality of life (Ge and Hokao 2006; Okulicz-Kozaryn 2013); and (c) quality of life analyses that focus on objective indicators such as climate characteristics, the availability of public services or the unemployment rate of cities (Ballas 2013; Kahn 1995; Zenker et al. 2013).
} 
Figure 1:

The rise of single households in Vienna and Austria (1971-2019)

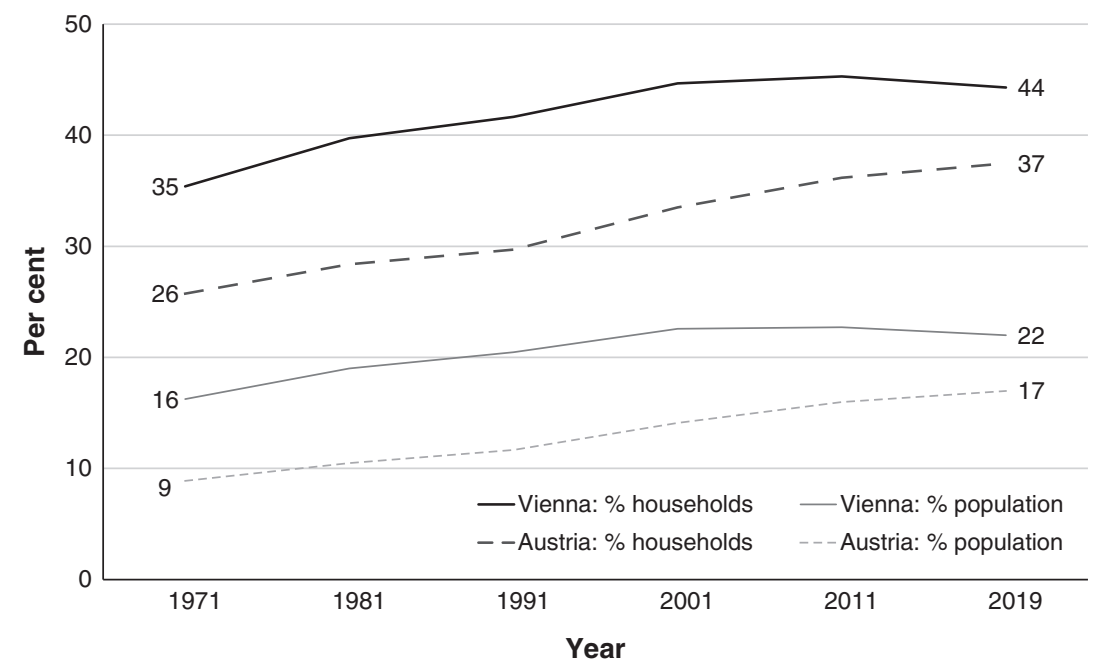

Notes: The graphs show the share of single households (i.e. one-person households) in total households (darker grey) and the share of persons living in single households in total population (lighter grey) for Vienna (continuous lines) and Austria (dotted lines). The figure for persons living in single households in Vienna in 2019 refers to 2017.

Source: Statistics Austria (2020).

larger share of the population who are living alone (e.g., 22 per cent in Vienna, 21 per cent in Brussels, 19 per cent in Stockholm, 18 per cent in Rome, 17 per cent in Paris) $)^{2}$ (Eurostat 2019).

\section{Theoretical concepts and hypotheses}

According to the literature, well-being is a relatively stable attribute that reflects the extent to which individuals experience positive affect and have favourable views of themselves and their lives (Kamp Dush and Amato 2005, p. 608). Some researchers have differentiated between an emotional component (positive and negative affect) and a cognitive component (life satisfaction as an evaluative judgement) of wellbeing. In our paper, we focus on the cognitive component of subjective wellbeing (i.e., satisfaction). We also rely on theoretical concepts of separate domains of subjective well-being. A glance at the literature reveals that a wide range of concepts to capture well-being have been proposed (Allardt 1976; Campbell et al. 1976; Diener 2009; Diener and Suh 1997; Tov and Diener 2007; Veenhoven 2000,

2 The data in the text refer to 2015 to 2017. Outliers are Madrid (12) or Berlin (31 per cent in 2012). The figures refer to the population living in private households. Institutional households are excluded. 
2007). Whereas Lindenberg, for instance, distinguished between material and social components (Ormel et al. 1999), ${ }^{3}$ Diener and Fujita (1995) referred to a related concept of material, personal and social resources that fulfil people's needs, and, in turn, enhance their well-being. ${ }^{4}$ Based on these concepts, we differentiate between material, social and cross-sectional domains of well-being. Material well-being refers to satisfaction with one's present housing situation and financial situation. Social well-being refers to satisfaction with one's family ties and social contacts. Finally, the cross-sectional domains refer to satisfaction with one's current main activity (e.g., employment) and leisure time activities. The latter two domains are both related to material as well as social well-being. Employment, for instance, is a main source of financial as well as social gratification; whereas leisure time activities depend on the person's time resources, social contacts and financial means. The concept of separate well-being domains can help to explain the differences between singles and other household types by pointing out how the situations of household types differ in specific life domains. In the following, we summarise the existing literature on the differences between various kinds of households in these domains, and present our resulting predictions in Table 1.

\subsection{Differences between singles and other household types regarding material well-being}

In terms of financial well-being, singles are less likely than other households to experience financial pressure due to commitments to a partner and/or children, and are more likely to feel free to spend money on themselves. In addition, because singles tend to have more (time) resources than other households to devote to their careers, they are more likely to achieve better-paid positions, and they may advance more quickly (Klinenberg 2012). Previous research has shown that in recent decades, the share of single-adult households in the middle-income segment has increased across OECD countries (Salvatori and Manfredi 2019, p. 34). By contrast, households with dependent children often have more difficulties making ends meet, and single-parent families in particular face a higher risk of falling below the poverty line in all EU member states, and in most OECD countries (Brady and Burroway 2012; Maldonado and Nieuwenhuis 2015; Riederer et al. 2017). For Austria, Zartler et al. (2011) found that compared to the total population, single-parent families are at least twice as likely to experience poverty. ${ }^{5}$ However,

\footnotetext{
3 Material components refer to factors such as health or wealth. Social components include friendship or love.

4 Material resources are external possessions (e.g., income, educational attainment and employment); personal resources are traits that enable people to cope with stress; and social resources are elements such as social integration and social support that help people achieve their valued outcomes.

5 Indications for increased labour market risks for single parent families have also been provided by Fritsch et al. (2019), Teitzer et al. (2014), Verwiebe and Fritsch (2011) and Verwiebe et al. (2013).
} 
Table 1:

Predictions from theoretical perspectives and empirical findings on differences in well-being domains between household types

\begin{tabular}{lcccc}
\hline & $\begin{array}{c}\text { Single } \\
\text { households }\end{array}$ & $\begin{array}{c}\text { Two adults } \\
\text { without } \\
\text { children }\end{array}$ & $\begin{array}{c}\text { Two adults } \\
\text { with } \\
\text { children }\end{array}$ & $\begin{array}{c}\text { Single } \\
\text { parents }\end{array}$ \\
\hline Material well-being & & & & \\
$\quad$ Financial resources & + & ++ & - & -- \\
$\quad$ Housing (incl. living environment) & + & ++ & -- & - \\
Social well-being & & & ++ & + \\
$\quad$ Romantic partnership and family & - & ++ & - & - \\
Friends and colleagues & ++ & + & & - \\
Cross-sectional domains & & & - & - \\
$\quad$ Leisure (personal autonomy) & + & ++ & - & - \\
Employment (career) & ++ & + & & \\
\hline
\end{tabular}

Source: Own illustration.

Note: + signifies advantages/positive effects on well-being, - signifies disadvantages/negative effects on well-being in the respective domain.

it has also been reported that two-adult households without children tend to have considerable financial advantages over single-person households (Verwiebe 2014, p. 297). Across Europe, 'the major share of upper middle-income and upperincome class households comprises non-retired adults without children' (VaughanWhitehead et al. 2016, p. 41). The presence of two earners enables the household to benefit from the pooling of financial resources and economies of scale. Financial gains are highest for childless dual-earner households who are not burdened with the need to spend on children (cf. Table 1).

Financial assets are also important for achieving high-quality housing arrangements. Couples without children (who can pool resources), but also people who live alone, are likely to have advantages in the housing market. Both household types are free to move and to change neighbourhoods if the benefits of doing so exceed the costs. As households with children are more dependent on the infrastructure of the neighbourhood (e.g., schools, health facilities), they are less flexible. Thus, the wellbeing of households with children may be negatively affected by the pressure to relocate (Ballas 2013, p. 44; Bratt 2002, p. 22). While households with children generally require more space, larger accommodations are often unaffordable, or are very distant from city centres (Ballas 2013, p. 45; Brown et al. 2016, p. 117). Furthermore, in Austria, homeowners are not necessarily more satisfied with their housing conditions than tenants (Elsinga and Hoekstra 2005, p. 422f). Overall, the literature suggests that singles have a slight advantage over other households in terms of housing satisfaction (Vera-Toscano and Ateca-Amestoy 2008, p. 262). 
Thus, we expect to find that singles have higher levels of material well-being than households with children, and single-parent households in particular; and that households made up of two adults without children who benefit from the pooling of their resources have the highest levels of material well-being (cf. Table 1).

\subsection{Differences between singles and other household types in terms of social well-being}

Previous research has shown that the well-being of different household types tends to differ considerably because of their varying levels of social embeddedness and their family ties. Single households are characterised by the absence of a permanently present second human being in the home. This absence often means more than the lack of a physical presence, as it can also mean the lack of emotional support. Although not everyone who lives alone is a 'single' in the sense of lacking an intimate relationship (Hertel et al. 2007), it may be assumed that the majority of individuals who live alone are not in a stable, long-term romantic relationship. ${ }^{6}$ In all cultures, families have been the fundamental building blocks of social life. Thus, the lack of an intimate relationship is often detrimental to an individual's subjective well-being (Klinenberg 2012). Helliwell (2003), for example, found that single people are, on average, less happy than (married) couples, especially if they had a previous partnership that ended (Ballas and Dorling 2007; Dolan et al. 2008). Similar findings have been reported for the U.S. by Kamp Dush and Amato (2005). They found that married couples reported the highest levels of subjective well-being, followed (in order) by individuals in cohabiting relationships, individuals in steady dating relationships, and individuals who dated infrequently or not at all. The most commonly accepted explanation for the link between well-being and family life is that being part of a family provides people with social support and social integration (Diener et al. 2000; Lee et al. 1991; Mastekaasa 1994; Shapiro and Keyes 2008). Studies indicated that individuals who are embedded in networks of supportive, helpful and loving or caring others tend to have better emotional health and higher levels of well-being. Against this background, we assume that singles and single parents are generally less satisfied with their family life than couples with or without children. However, we also expect to find that single households are less satisfied with their family life than single parents, because having children offers parents the opportunity to form stable, long-lasting and particularly strong emotional bonds (e.g., Huinink 1995; Morgan and King 2001) (cf. Table 1).

\footnotetext{
6 In the present paper, we conceptualise singles as individuals who live alone (Chandler et al. 2004; Hall and Ogden 2003; Hertel et al. 2007; Ogden and Hall 2000). Therefore, we cannot a priori preclude the possibility that they have a partner. Nevertheless, in our dataset, less than 30 per cent of individuals living alone were in a relationship, compared to 70 to 80 per cent of individuals in two-adult households (Appendix, Table A.2).
} 
Nevertheless, we should also consider the possibility that social well-being is less determined by an individual's family ties than ever before. Both psychological need theories (Baumeister and Leary 1995) as well as rational choice sociology (Nieboer and Lindenberg 2002) discuss the relevance of 'substitution effects'. According to these theories, a basic aim (e.g., belongingness) can be achieved by different means. Therefore, specific social relations and emotional bonds (e.g., within the family) may be substituted by others (e.g., friendship networks, close colleagues), and these kinds of substitution may go beyond the borders of different areas of private life. Hochschild (2001), for instance, observed that positive experiences in the workplace can compensate for negative experiences at home. Thus, in sum, being single does not necessarily mean that the individual lacks social relationships or contact with others; instead, it could mean that the person has more free time for fostering social contacts beyond the family of origin (Chandler et al. 2004). This leads us to assume that singles have more freedom to invest in non-family contacts than couples, and, in particular, couples with children (cf. Table 1). In contrast to single parents, people who live alone may be better able to compensate for their (potential) disadvantages in terms of their satisfaction with family life by forming social contacts above and beyond the confines of a nuclear family.

\subsection{Differences between singles and other household types regarding cross-sectional domains of well-being}

Leisure time and employment are life domains that are related to both financial and social well-being. Studies have, for instance, shown that having the time and the financial assets to connect with local communities and friends is a strong predictor of positive well-being (Ballas 2013, p. 44). Having social networks and friendships, but also engaging in solitary forms of leisure (such as educational, relaxational or physiological leisure activities) can enhance people's satisfaction with their leisure time, and, thus, their overall well-being (e.g., Heintzman 2020). Since singles are able to schedule their time independently, and have no immediate child care obligations, they likely are better able to arrange their leisure time around their personal preferences (Ateca-Amestoy et al. 2008; Lee and Bhargava 2004). Therefore, we expect to observe that singles are more satisfied with their leisure time than single parents and couples with children. At the same time, compared to couples, singles often feel greater pressure to actively keep in touch with their social networks (Klinenberg 2012) in order to avoid falling into a 'loner status' (Lawton and Cohen 1974, p. 198), which is characterised by a lack of interaction with both family and peers. Therefore, we expect to find that couples have the advantage of enjoying shared leisure time, which could lead to higher levels of overall well-being (cf. Table 1).

Satisfaction with one's employment is another important facet of subjective wellbeing. As a main activity, professional work gives life additional meaning, increases self-confidence and offers the opportunity for social and material gratification. In 
addition, Western societies generally value work orientation, and place considerable importance on employment (Fritsch et al. 2019). Thus, employment is considered a positive factor for life satisfaction (Frey and Stutzer 2002; Layard 2005; Schoon et al. 2005). In contrast, unemployment has been shown to have (long-lasting) negative effects on well-being, even if no income is lost (Berry and Okuliz-Kozaryn 2009, p. 120). Singles and single-parent households are likely to suffer more from the negative consequences of unemployment, since they are both financially selfreliant and socially dependent on contacts outside their own household. However, as singles are able to schedule their time independently and have no immediate child care obligations, they are able to put more emphasis on their careers than coupled individuals, or, in particular, adults with children (Klinenberg 2012). In addition, as singles are socially more dependent on contacts outside of their own household, their social contacts with colleagues may become crucial. Finally, the presence of a partner or of children in the household increases the likelihood of experiencing work-family conflicts, which can lead to lower satisfaction with work and reduced subjective well-being (e.g., Byron 2005; Matthews et al. 2006; Matysiak et al. 2016). Therefore, we assume that single households are, overall, more satisfied with their employment situations than other household types, and particularly compared to households with children (cf. Table 1).

\subsection{Considerations regarding the overall well-being of single households}

As we mentioned in the introduction, the question of whether the subjective wellbeing of single households is lower overall is anything but trivial. Our theoretical discussion clearly suggests that living alone has positive as well as negative consequences. Nevertheless, previous research has shown that singles tend to have lower subjective well-being than other types of households (e.g., Blekesaune 2018; Chang 2013; Mastekaasa 1994; Soons and Kalmijn 2009; Vanassche et al. 2013). If the overall life satisfaction of single households is shown to be lower than that of other households, this would, in turn, mean that family life contributes heavily to well-being, and that having advantages in other life domains would not fully compensate for this specific disadvantage.

However, according to our overview (Table 1), the family domain is the only one in which singles are clearly disadvantaged. Compared to each of the other household types we consider, the subjective well-being of single households is expected to be higher in some life domains, but lower in at least one. For instance, we assume that, on average, single households have higher levels of cross-sectional and material well-being than households with co-resident children. Couples without children seem to be best off, whereas single parents appear to face the most difficulties. It follows that we expect to find that the well-being of single households is lower than that of some household types, but is also higher than that of others. 


\subsection{Implicit assumptions: Domain satisfactions as mediators and the influence of background factors}

In the theoretical discussion, we identified a series of factors that may be responsible for the differences in domain satisfactions between single households and other household types. We further assume that these differences in domain satisfactions result in varying levels of overall well-being between different household types. For instance, we expect to find that for singles, their relationship status (i.e., the absence of an intimate partner) leads to lower satisfaction with family life, which, in turn, lowers their overall well-being. Our assumptions include two additional hypotheses. First, we assume throughout the paper that domain satisfactions mediate the association between household type and overall well-being. Second, we expect to observe that two types of background variables are at work: namely, confounders as well as mediators. The mediating role of life domain satisfactions follows directly from our theoretical starting point, and the assumption that a person's satisfaction with his/her individual life situation is an overall appraisal that is shaped by his/her levels of satisfaction in different life domains (cf. Diener 2009). The issue of how background factors can function as confounders or mediators requires a brief explanation. Different household types may have different characteristics that lead to advantages in some life domains, and disadvantages in others, which can, in turn, have positive and negative effects on overall life satisfaction. These characteristics may differ between households for at least two reasons. First, the household type may influence a characteristic that is relevant for an individual's well-being (i.e., mediating factors). Second, a background factor may affect both the household type and an individual's subjective well-being (i.e., confounding factors). ${ }^{7}$

Mediators comprise the equivalised household income and housing characteristics (e.g., the square footage each person has available or the living environment). These characteristics are affected by the type of household an individual lives in. As we outlined above, singles generally have less income than two-adult households (Verwiebe 2014, p. 297), but they also have more freedom to choose their living environment than households with children (e.g., Vera-Toscano and Ateca-Amestoy 2008). In turn, people's income and living environment are strong predictors of their well-being, and the lack of both in poor households negatively affects their wellbeing (Ballas 2013; Easterlin 2005). Age, gender, subjective health and immigration background are important confounders. Healthy women from Austrian families who are under age 25 or are over age 55 are the most likely to be living alone in Vienna (Statistik Journal Wien 2016, p. 22). At the same time, studies have shown that women experience higher levels of well-being than men when living

\footnotetext{
7 The authors acknowledge that the covariates presented below likely form even more complex multilateral relationships. The presented relationships are a simplified model of these interrelations, and other combinations should be further explored.
} 
alone (Ballas 2013; Hejj 1997); and that among singles, age typically forms a ushaped relationship with well-being (Ballas 2013; Brown et al. 2016; Clark and Oswald 2006; Fasang et al. 2016). People who are young and healthy might also find it easier to compensate for the lack of family ties with large networks of colleagues and friends (Chandler et al. 2004). Therefore, we expect to find that these factors not only increase the chances of living alone, but increase well-being per se. ${ }^{8}$

In sum, we hypothesise that confounders, mediators and life domain satisfactions explain large shares of the differences in levels of subjective well-being between single households and other household types. By using this approach, we seek to emphasise the complexity and the layered nature of the differences in wellbeing between household types. However, in our paper, we do not give the background factors centre stage. Instead, we investigate how domain satisfactions contribute to the differences in overall well-being between singles and other households.

\section{Data and methods}

\subsection{Data and variables}

Our analysis is based on a unique dataset that resulted from research collaborations undertaken by the University of Vienna and the City of Vienna. Between 1995 and 2018, data on living arrangements, living conditions, family issues, personal relationships, labour market behaviour, quality of life, health and happiness were collected in five cross-sectional surveys. The surveys were conducted by the IFES (www.ifes.at) in $1995(N=8,066), 2003(N=8,300), 2008(N=8,704), 2013$ $(N=8,400)$ and $2018(N=8,450)$. The methods of data collection comprise faceto-face interviews (1995-2008), computer-assisted telephone interviews (20032018) and computer-assisted web interviews (2018). The telephone interviews were based on random digit dialing (random last digit) to include mobile phone numbers. Most of the interviews were conducted in the German language. In addition, some immigrants from Turkey and the former Yugoslavia were interviewed in their mother tongue (300 interviews in 2003, 2008 and 2013; 350 in 2018). ${ }^{9}$ Random samples have been disproportionally stratified by districts to allow for regional analyses. The data are representative of the residential population of Vienna (aged

\footnotetext{
8 The classification of some covariates as mediators or confounders is debateable. In principle, a variable like employment status, for instance, could also be both, as it affects the household type, and it is affected by the household type (particularly from a longitudinal perspective). The measure of equivalent household income is, however, directly dependent on household type and household size. 9 In 2003 and 2008, face-to-face interviews were only used for interviews in foreign languages. In 2018, web interviews accounted for 23 per cent of all interviews.
} 
15 years and older), and cover 11,015 respondents living in single households (between 1,785 and 2,535 respondents in each wave). The IFES prepared (a) design weights that account for the variation in the selection probabilities of households and districts; (b) post-stratification weights that adjust for age by gender, education, district by gender and age and type of housing; and, in 2018, (c) weights that adjust the results for mode effects. We use a combined weight for all analyses presented here.

Based on the literature, we distinguish between dimensions of well-being using satisfaction with different life domains (Campbell et al. 1976; Diener and Fujita 1995; Ormel et al. 1999). The main variables of interest are the respondents' satisfaction with their housing (apartment or house) and their satisfaction with their financial situation as indicators of material well-being; the respondents' satisfaction with their family situation and with their social contacts (friends, acquaintances, etc.) as indicators of social well-being; and the respondents' satisfaction with their main activity (professional work, education or training, household labour, etc.) and with the time they have for leisure activities (e.g., cultural activities, sport activities, meeting friends) ${ }^{10}$ as indicators for cross-sectional life domains that affect and/or are being affected by material and social aspects of life. Finally, we also consider the respondents' satisfaction with their individual life situation as a whole, while assuming that life satisfaction is an overall appraisal that is shaped by people's satisfaction in different life domains (cf. Diener 2009). Respondents could rate their satisfaction in different domains or with life as a whole on five-point scales, ranging from one (very satisfied) to five (not satisfied at all). In the results section, we present the shares of respondents who were very satisfied or satisfied (values one and two) because these numbers are intuitively understood by readers (and sensitivity analyses with the original rating scales lead to the same conclusions). Descriptive analyses using the whole range of the scale (values from one to five) are shown in Table A.1 in the appendix.

In the following, we label background factors assumed to affect both household type and at least one domain of subjective well-being as confounders; and we label variables assumed to be affected by household type, and to affect subjective wellbeing, as mediators. Variables assumed to be confounders comprise partnership status measured by three variables (a) partner (romantic relationship: no/yes), ${ }^{11}$ (b) married (no/yes), (c) divorced or widowed (no/yes), gender (male/female), age (15 to 29,30 to 44,45 to 59,60 to 99 ), subjective health (very good (1), good (2), moderate (3), worse (four or five on a five-point rating scale)), employment

10 The wording regarding satisfaction with leisure time varied slightly across survey waves: in 2018, leisure activities explicitly included cultural activities, whereas in 1995, no examples of leisure time activities were mentioned. In 2003, 2008 and 2013, satisfaction with cultural activities was measured using a separate question.

11 Unfortunately, both the number and the wording of questions referring to the partner changed several times between survey waves. Some of these changes were unavoidable, as, for instance, the option of a registered partnership did not exist in 1995. 
status (employed, unemployed, other) and immigrant background (respondent or at least one of his/her parents not born in Austria). The variables assumed to have a mediating function include equivalised household income (quartiles), square meters per person in household (up to $25 \mathrm{~m}^{2}, 26$ to $35 \mathrm{~m}^{2}, 36$ to $45 \mathrm{~m}^{2}, 46$ to $70 \mathrm{~m}^{2}$, more than $70 \mathrm{~m}^{2}$ ) and the quality of the living environment (four categories ranging from 'no impairments' to 'some to major impairments'). The measure for the quality of the living environment is based on an index summarising subjective assessments of the quality of (a) air, (b) water supply, (c) road cleaning and (d) waste disposal. Descriptive statistics regarding confounders and mediators are shown in the appendix (Table A.2).

\subsection{Analysing strategy}

Our analytical strategy comprises three distinct steps. First, we describe the development of the subjective well-being of individuals living in single households over time, and compare it to the average subjective well-being of individuals in other selected living arrangements: namely, two-person households (with two adults), two adults living with at least one child (under 15 years old) and single-parent families (households with one adult and at least one child under 15 years old). This approach will allow us to compare the differences in the structure of wellbeing across household types. Second, we analyse the role of material, social and cross-sectional domains of well-being in the differences in overall life satisfaction between household types. To do so, we run a series of regression models employing hierarchical model building with a stepwise inclusion of domain satisfaction indicators. In binomial logistic regressions, we estimate average marginal effects, as these are the most likely to be comparable across different models (Mood 2010). The KHB method (Karlson et al. 2012) is used to examine whether differences in satisfaction with life domains account for the observed differences in overall life satisfaction between single households and other household types. This procedure enables us to draw conclusions about the mediating function of domain satisfactions. In addition, we use decomposition analysis to assess how much the differences in domain satisfactions contribute to the differences in overall life satisfaction between single households and other household types. Thus, these analyses also allow us to draw conclusions about substitution and compensation effects (as proposed by psychological need theories and rational choice authors). As our calculations are based on logistic models, we employ the method proposed by Fairlie (2005) and Jann (2006). Third, we examine the role of background factors (i.e., confounders and mediators) in differences between household types in domain satisfactions in further regression models. This approach allows us to assess the robustness of our assumptions described in Section 2.5. Finally, we perform complementary analyses that enable us to explore whether differences in confounders and mediators also contribute to observed differences in life satisfaction between single households and other household types (beyond their meaning for life domain satisfactions). 


\section{Results}

\subsection{Differences in subjective well-being across household types, 1995-2018}

Table 2 shows the development of the subjective well-being of single households, and compares individuals living in single households with other selected household types, as well as with the total population. Our analysis generated a number of important findings. Between 1995 and 2018, the overall life satisfaction levels of individuals living in single households remained quite stable. In each survey year, 74 to 80 per cent reported that they were satisfied with their life. In line with this general result, satisfaction with life domains was remarkably stable at a rather high level: i.e., at least 79 per cent of respondents in each survey year said they were satisfied with their social contacts, 75 per cent indicated they were satisfied with their leisure activities and 73 per cent said they were satisfied with their family

Table 2:

Differences in the subjective well-being of single households and other selected living arrangements 1995-2018 (\% very satisfied or satisfied)

\begin{tabular}{|c|c|c|c|c|c|c|}
\hline \multicolumn{2}{|c|}{$\begin{array}{c}\text { Subjective } \\
\text { well-being (SWB) }\end{array}$} & \multirow{2}{*}{$\begin{array}{c}\begin{array}{c}\text { Single } \\
\text { households }\end{array} \\
\% \\
\end{array}$} & \multirow{2}{*}{$\begin{array}{c}\text { Two adults } \\
\text { without } \\
\text { children }\end{array}$} & \multirow{2}{*}{$\begin{array}{c}\text { Two adults } \\
\text { with children } \\
\text { below age } 15\end{array}$} & \multirow{2}{*}{$\begin{array}{c}\begin{array}{c}\text { Single } \\
\text { parents }\end{array} \\
\text { Diff. }\end{array}$} & \multirow{2}{*}{$\begin{array}{c}\begin{array}{c}\text { Total } \\
\text { population }\end{array} \\
\text { Diff. } \\
\end{array}$} \\
\hline & & & & & & \\
\hline Overall & 1995 & 79 & $+10^{* * *}$ & $+5^{* * *}$ & $-5^{*}$ & +3 \\
\hline \multirow[t]{4}{*}{ life satisfaction } & 2003 & 79 & $+11^{* * *}$ & $+7^{* * *}$ & -3 & +4 \\
\hline & 2008 & 79 & $+9^{* * *}$ & $+7^{* * *}$ & -5 & +4 \\
\hline & 2013 & 80 & $+9^{* * *}$ & $+7^{* * *}$ & -1 & +3 \\
\hline & 2018 & $74^{\mathrm{b}}$ & $+11^{* * *}$ & $+7^{* * *}$ & -4 & +5 \\
\hline \multicolumn{7}{|c|}{ Domains of material WB } \\
\hline \multirow[t]{5}{*}{ Housing } & 1995 & 78 & +1 & $-15^{* * *}$ & $-14^{* * *}$ & -5 \\
\hline & 2003 & 80 & +1 & $-6^{* * *}$ & $-7^{* *}$ & -1 \\
\hline & 2008 & 79 & $+5^{* * *}$ & +1 & $-6^{*}$ & +2 \\
\hline & 2013 & $81^{\mathrm{c}}$ & $+2^{*}$ & -2 & -3 & 0 \\
\hline & 2018 & 78 & $+3^{*}$ & $-4^{* *}$ & $-16^{* * *}$ & -1 \\
\hline \multirow[t]{4}{*}{ Finances } & 2003 & 62 & $+12^{* * *}$ & -1 & $-13^{* * *}$ & +2 \\
\hline & 2008 & $65^{\mathrm{c}}$ & $+9^{* * *}$ & -1 & $-20^{* * *}$ & +2 \\
\hline & 2013 & $65^{c}$ & $+7^{* * *}$ & +1 & $-12^{* * *}$ & +3 \\
\hline & 2018 & 60 & $+11^{* * *}$ & 1 & $-12^{* * *}$ & +4 \\
\hline
\end{tabular}

Continued 
Table 2:

\section{Continued}

\begin{tabular}{|c|c|c|c|c|c|c|}
\hline \multirow{2}{*}{\multicolumn{2}{|c|}{$\begin{array}{c}\text { Subjective } \\
\text { well-being }(\mathrm{SWB})\end{array}$}} & $\begin{array}{c}\text { Single } \\
\text { households }\end{array}$ & $\begin{array}{c}\text { Two adults } \\
\text { without } \\
\text { children }\end{array}$ & $\begin{array}{c}\text { Two adults } \\
\text { with children } \\
\text { below age } 15\end{array}$ & $\begin{array}{c}\text { Single } \\
\text { parents }\end{array}$ & $\begin{array}{c}\text { Total } \\
\text { population }\end{array}$ \\
\hline & & $\%$ & Diff. & Diff. & Diff. & Diff. \\
\hline \multicolumn{7}{|c|}{ Domains of social WB } \\
\hline \multirow[t]{5}{*}{ Family } & 1995 & 73 & $+22^{* * *}$ & $+19^{* * *}$ & -2 & +11 \\
\hline & 2003 & 75 & $+18^{* * *}$ & $+17^{* * *}$ & 0 & +9 \\
\hline & 2008 & $76^{\mathrm{c}}$ & $+17^{* * *}$ & $+17^{* * *}$ & -2 & +8 \\
\hline & 2013 & $78^{\mathrm{a}}$ & $+16^{* * *}$ & $+15^{* * *}$ & -5 & +7 \\
\hline & 2018 & 73 & $+16^{* * *}$ & $+15^{* * *}$ & -1 & +8 \\
\hline \multirow[t]{5}{*}{ Social contacts } & 1995 & 87 & $+3^{* * *}$ & $+4^{* * *}$ & $+4^{*}$ & +2 \\
\hline & 2003 & 86 & $+6^{* * *}$ & $+4^{* *}$ & +2 & +2 \\
\hline & 2008 & $84^{\mathrm{b}}$ & $+6^{* * *}$ & $+3^{* *}$ & +3 & +3 \\
\hline & 2013 & 87 & $+3^{* * *}$ & $+2^{*}$ & -1 & +1 \\
\hline & 2018 & $79^{\mathrm{a}}$ & $+7^{* * *}$ & -2 & -1 & +1 \\
\hline \multicolumn{7}{|c|}{ Cross-sectional domains } \\
\hline \multirow[t]{4}{*}{ Main activity } & 2003 & 80 & $+5^{* * *}$ & 0 & $-8^{* * *}$ & +1 \\
\hline & 2008 & 80 & $+6^{* * *}$ & +1 & $-5^{*}$ & +2 \\
\hline & 2013 & 80 & $+8^{* * *}$ & $+6^{* * *}$ & -1 & +3 \\
\hline & 2018 & $74^{\mathrm{c}}$ & $+7^{* * *}$ & $+3^{*}$ & -2 & +3 \\
\hline \multirow[t]{5}{*}{ Leisure time } & 1995 & 77 & $+7^{* * *}$ & $-8^{* * *}$ & $-11^{* * *}$ & -1 \\
\hline & 2003 & 76 & $+6^{* * *}$ & $-3^{*}$ & -3 & +1 \\
\hline & 2008 & 77 & $+4^{* *}$ & $-6^{* * *}$ & $-11^{* * *}$ & 0 \\
\hline & 2013 & 78 & $+5^{* * *}$ & $-2^{*}$ & $-4^{*}$ & +1 \\
\hline & 2018 & 75 & 0 & $-24^{* * *}$ & $-16^{* * *}$ & -7 \\
\hline
\end{tabular}

Note: Differences have been measured in relation to single households. For instance, the difference of ' +10 ' for two adults without children with regard to life satisfaction in 1995 indicates that the share of satisfied persons was 10 percentage points higher among respondents from two-adult households than among respondents living in single households ( 89 per cent versus 79 per cent). Tests on differences between the respective multi-person households and single households: ${ }^{* * *} p \leq .001,{ }^{* *} p \leq .01,{ }^{*} p \leq .05$. Tests on differences between single households' satisfaction in the earliest available survey year (i.e., 1995 or 2003) and in the respective later survey year: ${ }^{\mathrm{a}} p \leq .001,{ }^{\mathrm{b}} p \leq .01$, ${ }^{\mathrm{c}} p \leq .05$.

Source: Viennese Quality of Life Surveys (1995-2018); $N=41,920$; own weighted calculations.

life. Up to 80 per cent reported that they were satisfied with their housing situation and with their main activity. However, the respondents reported feeling somewhat less satisfied with their financial situation (only 60 to 65 per cent said they were satisfied in each survey year). Overall, our results suggest that over the last two decades, the subjective well-being of single households in Vienna has, on average, been high. Compared to the total population, the well-being of single households 
hardly deviated from the average satisfaction levels in Vienna with regard to separate life domains, or to life in general. The level of life satisfaction was only slightly lower among single households (the share of people who were satisfied was three to five percentage points lower). However, there was one notable exception that is in line with our theoretical considerations (see section 2). While the share of people who were satisfied with their family life was at least 81 per cent among the total population of Vienna, this share was between seven and 11 percentage points lower among single households.

When we compare single households with selected other household types, we find the following: two-adult households without children were generally more satisfied than individuals who were living alone (average differences around 10 percentage points), in particular with regard to their financial situation (e.g., +11 percentage points in 2018) and their family life (+16). Likewise, two-adult households with children were more satisfied with their family life (e.g. +15 percentage points in 2018), but were less satisfied with the time they had for leisure activities than individuals who were living in single households. The decline in satisfaction with leisure activities (1995: -8 percentage points, 2018: -24 percentage points) in the two-adult households with children was especially remarkable. ${ }^{12}$ Finally, we observe that single parents were worse off in terms of their satisfaction with their housing, finances and leisure time. Overall, our findings demonstrate that there were household types that were more or less satisfied than single households, and that there were household types that were more satisfied in some dimensions of life, and were less satisfied in others. Nevertheless, it appears that the presence of an adult cohabitant had a strong positive effect on life satisfaction.

\subsection{The role of domain satisfactions in the differences in life satisfaction between single households and other household types}

Based on our regression models, Table 3 presents results on the relevance of material, social and cross-sectional domains of subjective well-being for differences in life satisfaction between households. Model M1 shows the observed differences between the single households and the other household types. The comparison of coefficients in Model M1 and Model M2 shows that the inclusion of material well-being reduces the differences in life satisfaction between single households and two-adult households (2003 and 2018), and between single households and single-parent households (2003 and 2018). For the latter, material well-being is absolutely crucial. In 2018, the difference between single parents and those living

\footnotetext{
12 One reason may be that the questionnaire in 2018 explicitly mentioned that leisure time activities include cultural activities, sport and meeting friends; while the 1995 questionnaire referred to the organisation of leisure time.
} 
Table 3:

Differences in overall life satisfaction (\% very satisfied or satisfied) between single households and other living arrangements 2003 and 2018 (AMEs)

\begin{tabular}{|c|c|c|c|c|c|}
\hline Overall life satisfaction & M1 & M2 & M3 & M4 & M5 \\
\hline \multicolumn{6}{|l|}{ Year 2003} \\
\hline \multicolumn{6}{|l|}{ Single households } \\
\hline Two adults without children & $.10^{* * *}$ & $.08^{* * * \mathrm{~b}}$ & $.04^{* * * a}$ & $.08^{* * * \mathrm{~d}}$ & $.04^{* * * *}$ \\
\hline $\begin{array}{l}\text { Two adults with children } \\
\text { below age } 15\end{array}$ & $.05^{* * *}$ & $.06^{* * *}$ & $-.01^{\mathrm{a}}$ & $.06^{* * *}$ & $.02^{*}$ \\
\hline Single parents & $-.04^{(*)}$ & $.01^{\mathrm{a}}$ & $-.04^{*}$ & $.00^{\mathrm{b}}$ & $.00^{\mathrm{b}}$ \\
\hline Other households & $.04^{* *}$ & $.04^{* * *}$ & $.00^{\mathrm{a}}$ & $.04^{* *}$ & .01 \\
\hline Cragg \& Uhler's R ${ }^{2}$ & 2.7 & 23.1 & 24.2 & 27.5 & 42.3 \\
\hline \multicolumn{6}{|l|}{ Year 2018} \\
\hline \multicolumn{6}{|l|}{ Single households } \\
\hline Two adults without children & $.11^{* * *}$ & $.07^{* * * \mathrm{c}}$ & $.05^{* * * a}$ & $.10^{* * *}$ & $.04^{* * * *}$ \\
\hline $\begin{array}{l}\text { Two adults with children } \\
\text { below age } 15\end{array}$ & $.07^{* * *}$ & $.07^{* * *}$ & $.03^{* \mathrm{c}}$ & $.09^{* * *}$ & $.05^{* * *}$ \\
\hline Single parents & $-.07^{*}$ & $.01^{\mathrm{a}}$ & $-.05^{(*)}$ & $-.02^{\mathrm{b}}$ & $.01^{\mathrm{a}}$ \\
\hline Other households & .01 & .01 & .00 & $.03^{*}$ & .01 \\
\hline Cragg \& Uhler's R ${ }^{2}$ & 2.5 & 21.6 & 32.7 & 28.7 & 49.6 \\
\hline $\begin{array}{l}\text { Domains of material WB } \\
\text { Domains of social WB }\end{array}$ & & incl. & incl. & & $\begin{array}{l}\text { incl. } \\
\text { incl. }\end{array}$ \\
\hline Cross-sectional domains & & & & incl. & incl. \\
\hline Differences between models & & $\operatorname{lr} \mathrm{chi}^{2}$ & $\operatorname{lr} \mathrm{chi}^{2}$ & $\operatorname{lr} \mathrm{chi}^{2}$ & $\operatorname{lr} \mathrm{chi}^{2}$ \\
\hline Tests vs. M1: Year 2003 & ref. & $993^{* * *}$ & $1051^{* * *}$ & $1221^{* * *}$ & $2056^{* * *}$ \\
\hline Year 2018 & ref. & $1630^{* * *}$ & $1739^{* * *}$ & $1486^{* * *}$ & $2906^{* * *}$ \\
\hline
\end{tabular}

Notes: The table gives average marginal effects (AMEs). Life domains satisfaction measures refer to housing and financial situation (domains of material well-being), family life and social contacts (domains of social well-being), and main activity and leisure time (cross-sectional domains). Tests referring to coefficients: (a) Tests on differences compared to single households: ${ }^{* * *} p \leq .001,{ }^{* *} p \leq .01,{ }^{*} p \leq .05,{ }^{(*)} p \leq .06$; (b) tests on differences compared to M1: ${ }^{\mathrm{a}} p \leq .001,{ }^{\mathrm{b}} p \leq .01,{ }^{\mathrm{c}} p \leq .05,{ }^{\mathrm{d}} p \leq .06$.

Source: Viennese Quality of Life Surveys (2003, 2018); $N_{2003}=7.866 ; N_{2018}=8.051$; own unweighted calculations.

alone was -.07 in Model M1, but was +.01 in Model M2. This means that the observed share of respondents satisfied with their life was seven percentage points lower among single parents than among single households in 2018. If, however, the two groups had not differed in terms of their material well-being, the difference would have completely disappeared. Material well-being was not as relevant for the life satisfaction differences between single households and two-adult households 
without children. In 2018, the observed difference in the share of respondents who were satisfied with their life decreased from eleven (M1) to seven percentage points (M2). Comparing the coefficients in Model M1 and Model M3 demonstrates that social well-being was highly relevant for differences in life satisfaction between single households and two-adult households (with and without children). The differences between single households and respondents from two-adult households without children were reduced by six percentage points in both 2003 and 2018, and the differences between single households and respondents from two-adult households with children disappeared entirely in 2003 , and were reduced by four percentage points in 2018.

The results for the cross-sectional domains of well-being (M4) were similar to those for material well-being, and were mainly relevant for the differences between single households and single-parent households. Together, the differences in the material, social and cross-sectional domains of subjective well-being accounted completely for the differences between single households and single-parent households, and partly explained the differences between single households and two-adult households (with or without children) in both 2003 and 2018 (M5).

The results of our decomposition analyses (Table 4) reflect the main results of the regression analyses (Table 3, M1 and M5), and provide some additional insights regarding the role of domain satisfactions in overall life satisfaction. Table 4 again shows that the share of respondents who were satisfied with their life was about 10 (2003) to 11 (2018) percentage points lower among single households than among two-adult households without children. By and large, seven of those 10 to 11 percentage points could be explained by differences in domain satisfactions. The most relevant indicator was satisfaction with family life, which accounted for about four percentage points. Thus, lower satisfaction with family life was the main driver of lower life satisfaction among single households. For households with two adults and children under age 15, the results were very similar, but were still different. The share of respondents satisfied with their life was about five to seven percentage points lower among single households than it was among households with two adults and children. Again, lower satisfaction with family life accounted for about four percentage points. However, higher levels of satisfaction among single households with their housing, financial situation, main activity (only 2003) and leisure time (only 2018) helped to offset their disadvantage in satisfaction with family life. Thus, there were at least weak compensation effects related to higher levels of satisfaction in material and cross-sectional domains of well-being.

Finally, the differences in life satisfaction levels between single households and single parents were completely explained by differences in domain satisfactions. Regression analyses (Table 3) already showed that material and cross-sectional domains of well-being were decisive for the higher life satisfaction levels among single households. Decomposition analyses (Table 4) now reveal that the respondents' satisfaction with their financial situation contributed the most to their differences in life satisfaction. However, the higher levels of satisfaction among single households with their housing, main activity and leisure time also contributed to the difference 
Table 4:

Decomposition analyses to explain differences in overall life satisfaction between single households and other household types by differences in dimensions of well-being $(\%)$

\begin{tabular}{|c|c|c|c|c|c|c|}
\hline \multirow{2}{*}{$\begin{array}{l}\text { Overall } \\
\text { life } \\
\text { satisfaction } \\
\text { Share satisfied (\%) }\end{array}$} & \multicolumn{2}{|c|}{$\begin{array}{c}\text { (1) Single } \\
\text { households } \\
\text { vs. two } \\
\text { adults } \\
\text { without children }\end{array}$} & \multicolumn{2}{|c|}{$\begin{array}{c}\text { (2) Single } \\
\text { households } \\
\text { vs. two adults } \\
\text { with children } \\
\text { below age } 15\end{array}$} & \multicolumn{2}{|c|}{$\begin{array}{c}\text { (3) Single } \\
\text { households vs. } \\
\text { single parents }\end{array}$} \\
\hline & 2003 & 2018 & 2003 & 2018 & 2003 & 2018 \\
\hline Single households & 80.52 & 75.56 & 80.52 & 75.56 & 80.52 & 75.56 \\
\hline $\begin{array}{l}\text { Other household } \\
\text { type }\end{array}$ & 90.83 & 86.64 & 85.91 & 82.56 & 76.35 & 68.49 \\
\hline Difference & -10.31 & -11.08 & -5.39 & -7.00 & 4.17 & 7.07 \\
\hline Explained & -6.88 & -7.54 & -3.18 & -2.50 & 3.91 & 7.15 \\
\hline \multicolumn{7}{|c|}{ Domains of material WB } \\
\hline Housing & $.14^{* * *}$ & $-.09^{* * *}$ & $.73^{* * *}$ & $.75^{* * *}$ & $.92^{* * *}$ & $2.20^{* * *}$ \\
\hline Finances & $-.79^{* * *}$ & $-1.21^{* * *}$ & $.93^{* * *}$ & $.38^{* * *}$ & $2.47^{* * *}$ & $2.64^{* * *}$ \\
\hline \multicolumn{7}{|l|}{ Domains of social WB } \\
\hline Family & $-4.01^{* * *}$ & $-3.88^{* * *}$ & $-4.30^{* * *}$ & $-4.03^{* * *}$ & $-.97^{* * *}$ & $-.13^{*}$ \\
\hline Social contacts & $-.95^{* * *}$ & $-1.47^{* * *}$ & $-.84^{* * *}$ & $-.20^{* * *}$ & $-.52^{* * *}$ & $.48^{* * *}$ \\
\hline \multicolumn{7}{|c|}{ Cross-sectional domains } \\
\hline Main activity & $-.50^{* * *}$ & $-.91^{* * *}$ & $.59^{* * *}$ & $-.24^{* * *}$ & $1.71^{* * *}$ & $1.06^{* * *}$ \\
\hline Leisure time & $-.79^{* * *}$ & $.01^{*}$ & $-.28^{* * *}$ & $.78^{* * *}$ & $.23^{* * *}$ & $.91^{* * *}$ \\
\hline$N_{\text {single households }}$ & 2274 & 2205 & 2274 & 2205 & 2274 & 2205 \\
\hline$N_{\text {other household type }}$ & 2126 & 2290 & 1810 & 1141 & 427 & 238 \\
\hline
\end{tabular}

Source: Viennese Quality of Life Surveys (2003, 2018); own unweighted calculations.

(in particular in 2018). Overall, our findings clearly demonstrate that the lower levels of social well-being (mainly due to lower satisfaction with the family situation) among single households was only partly compensated for by their higher levels of satisfaction in material and cross-sectional domains of well-being. Compared to single-parent households and two-adult households with children, the levels of life satisfaction among single households were positively affected by their higher levels of satisfaction with their housing, financial situation and (in particular in 2018) leisure time. The highest levels of life satisfaction were, however, experienced by two-adult households without children. These households enjoyed high levels of satisfaction with their family life, and had no disadvantages in the material or crosssectional domains of well-being. 


\subsection{Background factors accounting for the differences in domain satisfaction between single households and other household types}

Above, we showed that differences in domain satisfactions were (partly) responsible for differences in life satisfaction. In the next step, we want to disentangle the background factors that are related to differences in the material, social and crosssectional domains of well-being. The detailed results of Table 5 are in line with our conceptual assumptions. For instance, we found that a higher income increased all sub-dimensions of well-being, except satisfaction with leisure time. Being unemployed was associated with reduced satisfaction with one's main activity and finances. Having a partner was linked to improved satisfaction with one's family life and social contacts. Being married was associated with higher satisfaction with one's family life, leisure time, housing and main activity. Being in bad health and having a low-quality living environment both negatively affected all sub-dimensions of subjective well-being. As single households differed from other household types in one or more of these characteristics (see Table A.2), they explained a huge part of the differences in life domain satisfaction observed between household types.

The results of regression models shown in Table 5 reveal that background factors (i.e., confounders and mediators) entirely accounted for the differences between single households and single parents in their levels of satisfaction with their housing, financial situation and main activity. These material and cross-sectional domains of satisfaction were affected by income, square meters of living space per person and employment status; i.e., factors in which single households and single-parent households clearly differed (Table A.2). Additionally, background factors partly explained the differences between single households and single-parent households in terms of their satisfaction with their leisure time. Most importantly, however, the differences in these characteristics between single households and respondents from two-adult households without children explained significant parts of the differences in their social well-being (i.e., satisfaction with family life and social contacts; cf. Table 5).

\subsection{Life satisfaction of households being shaped by domain satisfactions and background factors}

Background factors play a role in life satisfaction beyond their significance for domain satisfactions. Taken together, the differences in background factors and domain satisfaction completely explained the observed differences in life satisfaction between single households and other household types (Model A5 in Table A.3). The inclusion of confounding variables like relationship status, gender, age, health, employment and immigrant background reduced the differences between single households and two-adult households (2003 and 2018), respondents living with a second adult and children (2018), and single-parent households (2003 and 2018; cf. 
Table 5:

Differences in dimensions of subjective well-being (\% very satisfied or satisfied) between single households and other household types 2018 (AMEs)

\begin{tabular}{|c|c|c|c|c|c|c|}
\hline \multirow{2}{*}{$\begin{array}{l}\text { Subjective } \\
\text { well-being: } \\
\text { Share of those } \\
\text { satisfied with }\end{array}$} & \multicolumn{2}{|c|}{$\begin{array}{c}\text { Domains of } \\
\text { material WB }\end{array}$} & \multicolumn{2}{|c|}{$\begin{array}{c}\text { Domains of } \\
\text { social WB }\end{array}$} & \multicolumn{2}{|c|}{$\begin{array}{l}\text { Cross-sectional } \\
\text { domains }\end{array}$} \\
\hline & Housing & Finances & Family & $\begin{array}{c}\text { Social } \\
\text { contacts }\end{array}$ & $\begin{array}{c}\text { Main } \\
\text { activity }\end{array}$ & $\begin{array}{c}\text { Leisure } \\
\text { time }\end{array}$ \\
\hline \multicolumn{7}{|c|}{ Models without background factors } \\
\hline \multicolumn{7}{|c|}{ Single households } \\
\hline Two adults without children & $.04^{* * *}$ & $.11^{* * *}$ & $.15^{* * *}$ & $.06^{* * *}$ & $.07^{* * *}$ & -.01 \\
\hline $\begin{array}{l}\text { Two adults with children } \\
\text { below age } 15\end{array}$ & $-.04^{*}$ & .01 & $.15^{* * *}$ & -.02 & $.03^{*}$ & $-.22^{* * *}$ \\
\hline Single parents & $-.15^{* * *}$ & $-.15^{* * *}$ & -.03 & -.03 & -.04 & $-.19^{* * *}$ \\
\hline Other households & $-.04^{* * *}$ & .02 & $.05^{* * *}$ & -.01 & .00 & $-.09^{* * *}$ \\
\hline \multicolumn{7}{|c|}{ Models with background factors } \\
\hline \multicolumn{7}{|l|}{ Single households } \\
\hline $\begin{array}{l}\text { Two adults without children } \\
\text { below age } 15\end{array}$ & $.06^{* * *}$ & $.03^{(*) \mathrm{a}}$ & $.10^{* * * a}$ & $.02^{\mathrm{a}}$ & $.01^{\mathrm{a}}$ & -.03 \\
\hline Two adults with children & $.09^{* * * a}$ & $.05^{* \mathrm{c}}$ & $.13^{* * *}$ & -.01 & $.04^{(*)}$ & $-.13^{* * * \mathrm{a}}$ \\
\hline Single parents & $.06^{* \mathrm{a}}$ & $.04^{\mathrm{a}}$ & $.04^{\mathrm{a}}$ & $.03^{\mathrm{a}}$ & $.06^{* \mathrm{a}}$ & $-.07^{* \mathrm{a}}$ \\
\hline Other households & $.10^{* * * \mathrm{a}}$ & $.09^{* * * \mathrm{a}}$ & $.07^{* * *}$ & $.02^{\mathrm{c}}$ & $.04^{* * \mathrm{c}}$ & $-.04^{* \mathrm{a}}$ \\
\hline \multicolumn{7}{|l|}{ Confounders } \\
\hline \multicolumn{7}{|l|}{ Relationship status: } \\
\hline Partner $(0 / 1)$ & -.02 & $.04^{* *}$ & $.06^{* * *}$ & $.05^{* * *}$ & .02 & .00 \\
\hline Married $(0 / 1)$ & $.06^{* * *}$ & .01 & $.03^{*}$ & .02 & $.04^{* *}$ & $.04^{*}$ \\
\hline Divorced/widowed (0/1) & $-.03^{*}$ & -.02 & -.01 & .01 & $.03^{*}$ & .03 \\
\hline Gender: female $(0 / 1)$ & -.01 & $-.02^{(*)}$ & .00 & $.03^{* * *}$ & -.01 & -.02 \\
\hline Age: 15 to $29 \mathrm{yrs}$. & .00 & .02 & .01 & $.03^{*}$ & .01 & .01 \\
\hline 30 to 44 yrs. & ref. & ref. & ref. & ref. & ref. & ref. \\
\hline 45 to 59 yrs. & $.03^{*}$ & $.07^{* * *}$ & $.06^{* * *}$ & $.05^{* * *}$ & $.03^{*}$ & $.08^{* * *}$ \\
\hline 60 to 99 yrs. & $.07^{* * *}$ & $.17^{* * *}$ & $.14^{* * *}$ & $.12^{* * *}$ & $.14^{* * *}$ & $.24^{* * *}$ \\
\hline Subjective health: very good & ref. & ref. & ref. & ref. & ref. & ref. \\
\hline Good & $-.04^{* * *}$ & $-.09^{* * *}$ & $-.07^{* * *}$ & $-.09^{* * *}$ & $-.08^{* * *}$ & $-.09^{* * *}$ \\
\hline Moderate & $-.09^{* * *}$ & $-.19^{* * *}$ & $-.16^{* * *}$ & $-.19^{* * *}$ & $-.20^{* * *}$ & $-.17^{* * *}$ \\
\hline Worse & $-.13^{* * *}$ & $-.24^{* * *}$ & $-.20^{* * *}$ & $-.2^{* * *}$ & $-.26^{* * *}$ & $-.23^{* * *}$ \\
\hline Employment: unemployed & .00 & $-.11^{* * *}$ & -.02 & -.02 & $-.18^{* * *}$ & .02 \\
\hline In employment & -.02 & -.02 & -.01 & -.01 & .01 & $-.10^{* * *}$ \\
\hline Others & ref. & ref. & ref. & ref. & ref. & ref. \\
\hline Immigrant background $(0 / 1)$ & $-.02^{*}$ & .00 & $-.04^{* * *}$ & $-.02^{(*)}$ & .00 & -.02 \\
\hline \multicolumn{7}{|l|}{ Mediators } \\
\hline \multicolumn{7}{|l|}{ Equivalised household } \\
\hline Income: lower $25 \%$ & $-.06^{* * *}$ & $-.24^{* * *}$ & $-.03^{*}$ & $-.03^{*}$ & $-.06^{* * *}$ & -.02 \\
\hline 26 to $50 \%$ & $-.04^{* * *}$ & $-.14^{* * *}$ & -.02 & -.02 & -.02 & -.01 \\
\hline 51 to $75 \%$ & ref. & ref. & ref. & ref. & ref. & ref. \\
\hline 76 to $100 \%$ & $.03^{*}$ & $.16^{* * *}$ & $.04^{*}$ & $.05^{* *}$ & $.06^{* * *}$ & -.03 \\
\hline
\end{tabular}

Continued 
Table 5:

Continued

\begin{tabular}{|c|c|c|c|c|c|c|}
\hline \multirow{2}{*}{$\begin{array}{l}\text { Subjective } \\
\text { well-being: } \\
\text { Share of those } \\
\text { satisfied with }\end{array}$} & \multicolumn{2}{|c|}{$\begin{array}{c}\text { Domains of } \\
\text { material WB }\end{array}$} & \multicolumn{2}{|c|}{$\begin{array}{c}\text { Domains of } \\
\text { social WB }\end{array}$} & \multicolumn{2}{|c|}{$\begin{array}{c}\text { Cross-sectional } \\
\text { domains }\end{array}$} \\
\hline & Housing & Finances & Family & $\begin{array}{c}\text { Social } \\
\text { contacts }\end{array}$ & $\begin{array}{c}\text { Main } \\
\text { activity }\end{array}$ & $\begin{array}{c}\text { Leisure } \\
\text { time }\end{array}$ \\
\hline \multicolumn{7}{|l|}{ Square meters per person: } \\
\hline Up to $25 \mathrm{~m}^{2}$ & $-.10^{* * *}$ & .01 & .00 & -.01 & -.01 & -.02 \\
\hline 26 to $35 \mathrm{~m}^{2}$ & ref. & ref. & ref. & ref. & ref. & ref. \\
\hline 36 to $45 \mathrm{~m}^{2}$ & $.05^{* * *}$ & $.03^{*}$ & -.02 & .00 & .01 & .00 \\
\hline 46 to $70 \mathrm{~m}^{2}$ & $.10^{* * *}$ & $.05^{* * *}$ & .01 & .01 & .02 & .03 \\
\hline More than $70 \mathrm{~m}^{2}$ & $.16^{* * *}$ & $.07^{* * *}$ & .00 & .03 & .02 & .00 \\
\hline \multicolumn{7}{|l|}{ Living environment: } \\
\hline No impairments & ref. & ref. & ref. & ref. & ref. & ref. \\
\hline Almost no impairments & $-.04^{* * *}$ & $-.02^{(*)}$ & $-.03^{* * *}$ & $-.03^{*}$ & -.02 & $-.06^{* * *}$ \\
\hline Rarely impairments & $-.13^{* * *}$ & $-.08^{* * *}$ & $-.07^{* * *}$ & $-.07^{* * *}$ & $-.07^{* * *}$ & $-.11^{* * *}$ \\
\hline Some to major impairments & $-.26^{* * *}$ & $-.17^{* * *}$ & $-.12^{* * *}$ & $-.14^{* * *}$ & $-.13^{* * *}$ & $-.18^{* * *}$ \\
\hline Cragg \& Uhler's $\mathrm{R}^{2}$ & 24.8 & 28.3 & 20.2 & 18.4 & 21.7 & 18.1 \\
\hline
\end{tabular}

Note: The table gives average marginal effects (AME). ${ }^{* *} p \leq .001,{ }^{* *} p \leq .01,{ }^{*} p \leq .05,{ }^{(*)} p \leq .06$. Tests on differences compared to the model without confounders and mediators: ${ }^{\mathrm{a}} p \leq .001,{ }^{\mathrm{b}} p \leq .01,{ }^{\mathrm{c}} p \leq .05,{ }^{\mathrm{d}} p \leq .06$. The quality of the living environment refers to the absence of problems with quality of air, water supply, road cleaning and waste disposal.

Source: Viennese Quality of Life Survey (2018); $N=8.051$; own unweighted calculations.

Model A2 in Table A.3). The mediators - equivalised household income, square meters per person and quality of the living environment - were mainly relevant for the differences in life satisfaction between single households and single-parent households. On average, the single-parent households had lower household income and less living space per person, and were more likely to be living in an area with lower environmental quality. Our results even suggest that single parents would have been more satisfied with their life than single households in 2018 if there had been no differences in these characteristics between the two groups (Models A3 and A4).

Finally, our findings clearly support the hypothesis that domain satisfactions function as mediators. Table 5 shows associations between household types and domain satisfactions. Moreover, Table 4 displays the influence of higher levels of satisfaction with social, material and cross-sectional domains of well-being on life satisfaction. The results of KHB tests support the mediating assumption (Tables 3 and A.3). However, when we look at the background factors, we see that being divorced or widowed (only in 2003), being aged 60+ (only in 2018), health, employment status, household income and the quality of the living environment (all 2003 and 2018) had effects on life satisfaction that were only partly mediated by life domain satisfactions (results from Model A5 in Table A.3). 


\section{Discussion}

Individualisation and urbanisation have led to substantial changes in household structures (Bengtson 2001; Hall et al. 1997). Living alone has become a common phenomenon, especially in growing metropolitan regions. Nevertheless, research on the subjective well-being of urban single households is still sparse. The present paper sought to address this research gap by examining the dynamics in the quality of life of single households in Vienna over a quarter of a century (1995-2018). Based on a unique dataset, we obtained a number of important findings. First, we showed that four in five individuals living in single households were satisfied with their lives. Moreover, this high level of average satisfaction among single households was very stable over time. Thus, we found that singles were (almost) as satisfied with life as the average population of Vienna. Assessing whether single households were worse off than other household types was not straightforward. Apparently, the comparison standard matters: the life satisfaction of two-adult households (with and without children) was significantly higher than that of single households, whereas the life satisfaction of single parents was not. Second, our findings demonstrated that satisfaction with family life was considerably lower in single households than in the average population. Decomposition analyses showed that differences in satisfaction with family life were the main reason for the lower levels of life satisfaction among single households than among two-adult households with and without children. Thus, our findings support previous research that has attributed the lower subjective well-being observed among singles to missing social support, a lack of social integration and an unsatisfied feeling of belonging (Diener et al. 2000; Lee et al. 1991; Mastekaasa 1994; Shapiro and Keyes 2008).

Third, we found that among singles, their higher levels of satisfaction in other life domains partly compensated for their lower satisfaction with family life. Our results showed, for instance, that for single households, their higher levels of satisfaction with their housing, financial situation, main activity and leisure time helped to offset their disadvantages relative to two-adult households with children. These findings imply that living alone has advantages and disadvantages (although twoadult households without children seem to have the highest levels of subjective wellbeing). These results are also in line with theories that refer to substitution effects (Baumeister and Leary 1995; Nieboer and Lindenberg 2002). Fourth, our findings showed that the lower satisfaction with family life found among singles was not always decisive. Single parents who reported a comparable level of satisfaction with family life had, on average, lower levels of life satisfaction than single households because of their lower levels of material well-being. The factor that was most relevant for the finding that single-parent households had lower life satisfaction than single households was that these respondents were less satisfied with their financial situation. In addition, single-parent households were less satisfied with their housing and leisure time. These results are not surprising given that single parents are known to face many difficulties (Brady and Burroway 2012; Damaske et al. 2017; Riederer et al. 2017). Nevertheless, together with the evidence for compensation effects, these 
findings go beyond the usual focus on family issues in the academic discussion of subjective well-being among singles. Thus, these results enrich our understanding of the differences in well-being between household types.

In a nutshell, our results confirmed that a variety of factors accounted for the differences we observed between household types in levels of life satisfaction. These differences could be completely explained by domain satisfaction and background factors, and the differences in domain satisfaction could also be largely explained by the latter. These findings suggest that the household type per se was not decisive for subjective well-being. More important were factors that led to living alone (e.g., not having a partner) or factors that may have followed from being a single parent (e.g., economic hardship). There were always reasons for the advantages or disadvantages in well-being we found for a specific household type. While our study has taken a first step towards providing a more detailed picture of single households, future studies are needed that focus on other household types, and that analyse them more systematically.

Finally, our study has several limitations. The primary limitation is that we did not distinguish between singles (people without a partner) and one-person households and between two-adult households and couple households. ${ }^{13}$ The reason for this issue was that both the number and the wording of questions referring to the partner changed between survey waves several times. Thus, we decided to use broader categories of household types that were comparable over time. In addition, the single households were very heterogeneous in several other respects (gender, age, income etc.). Thus, our next step will be to perform an analysis of differences within the group of single households in Vienna.

\section{References}

Allardt, E. 1976. Dimensions of welfare in a comparative Scandinavian study. Acta Sociologica 19(3): 227-239. https://doi.org/10.1177/000169937601900302

Ateca-Amestoy, V., R. Serrano-del-Rosal and E. Vera-Toscano 2008. The leisure experience. The Journal of Socio-Economics 37(1): 64-78. https://doi.org/10.1016/j.socec.2006.12. 025

Ballas, D. 2013. What makes a 'happy city'? Cities 32(S1): S39-S50. https://doi.org/10. 1016/j.cities.2013.04.009

Ballas, D. and D. Dorling 2007. Measuring the impact of major life events upon happiness. International Journal of Epidemiology 36(6): 1244-1252. https://doi.org/10.1093/ije/ dym182

13 Besides couples, two-adult households also comprise shared flats or parent-child households. In 2018, for instance, about 70 to 80 per cent of two-adult households (without/with children) were couple households (cf. Table A.2). 
Baumeister, R. F. and M. R. Leary 1995. The need to belong: Desire for interpersonal attachments as a fundamental human motivation. Psychological Bulletin 117(3): 497-529. https://doi.org/10.1037/0033-2909.117.3.497

Bengtson, V. 2001. Beyond the nuclear family: The increasing importance of multigenerational bonds. Journal of Marriage and Family 63(1): 1-16. https://doi.org/10.1111/j.17413737.2001.00001.x

Bennett, J. and M. Dixon 2006. Single person households and social policy: Looking forwards. York: Joseph Rowntree Foundation.

Berry, B. and A. Okuliz-Kozaryn 2009. Dissatisfaction with city life: A new look at some old questions. Cities 26(3): 117-124. https://doi.org/10.1016/j.cities.2009.01.005

Bertram, H. 1993. Die Stadt, das Individuum und das Verschwinden der Familie. Berlin: Humboldt-Universität zu Berlin. https://doi.org/10.18452/1538

Blekesaune, M. 2018. Is cohabitation as good as marriage for people's subjective well-being? Journal of Happiness Studies 19(2): 505-520. https://doi.org/10.1007/s10902-016-9834-X

Bouzarovski, S., A. Haase, R. Hall, A. Steinführer, S. Kabisch and P. Ogden 2010. Household structure, migration trends, and residential preferences in inner-city León, Spain: Unpacking the demographies of reurbanization. Urban Geography 31(2): 211-235. https://doi.org/10.2747/0272-3638.31.2.211

Brady, D. and R. Burroway 2012. Targeting, universalism, and single-mother poverty: A multilevel analysis across 18 affluent democracies. Demography 49(2): 719-746. https: //doi.org/10.1007/s13524-012-0094-z

Bratt, R. 2002. Housing and family well-being. Housing Studies 17(1): 13-26. https://doi. org/10.1080/02673030120105857

Brown, Z., W. Oueslati and J. Silva 2016. Links between urban structure and life satisfaction in a cross-section of OECD metro areas. Ecological Economics 129: 112-121. https: //doi.org/10.1016/j.ecolecon.2016.05.004

Buzar, S., P. Ogden and R. Hall 2005. Households matter: The quiet demography of urban transformation. Progress in Human Geography 29(4): 413-436. https://doi.org/10.1191/ $0309132505 \mathrm{ph} 558 \mathrm{oa}$

Byron, K. 2005. A meta-analytic review of work-family conflict and its antecedents. Journal of Vocational Behavior 67(2): 169-198. https://doi.org/10.1016/j.jvb.2004.08.009

Campbell, A., P. Converse and W. Rogers 1976. The quality of american life: Perceptions, evaluations, and satisfactions. New York: Russell Sage Foundation.

Chandler, J., M. Williams, M. Maconachie, T. Collett and B. Dodgeon 2004. Living alone: Its place in household formation and change. Sociological Research Online 9(3): 1-13. https://doi.org/10.5153/sro.971

Chang, W.-C. 2013. Family ties, living arrangement, and marital satisfaction. Journal of Happiness Studies 14(1): 215-233. https://doi.org/10.1007/s10902-012-9325-7

Cherlin, A. 2004. The deinstitutionalization of American marriage. Journal of Marriage and Family 66(4): 848-861. https://doi.org/10.1111/j.0022-2445.2004.00058.x

Clark, A. and A. Oswald 2006. The curved relationship between subjective well-being and age. Paris: HAL Archive. Retrieved from https://halshs.archives-ouvertes.fr/halshs00590404/ 
Damaske, S., J. Bratter and A. Frech 2017. Single mother families and employment, race, and poverty in changing economic times. Social Science Research 62: 120-133. https: //doi.org/10.1016/j.ssresearch.2016.08.008

Diener, E. 2009. Assessing well-being. Netherlands: Springer. https://doi.org/10.1007/97890-481-2354-4

Diener, E. and Fujita 1995. Resources, personal strivings, and subjective well-being: A nomothetic and idiographic approach. Journal of Personality and Social Psychology 68(5): 926-935. https://doi.org/10.1037/0022-3514.68.5.926

Diener, E., C. Gohm, E. Suh and S. Oishi 2000. Similarity of the relations between marital status and subjective well-being across cultures. Journal of Cross-Cultural Psychology 31(4): 419-436. https://doi.org/10.1177/0022022100031004001

Diener, E. and E. M. Suh 1997. Measuring quality of life: Economic, social, and subjective indicators. Social Indicators Research 40: 189-216. https://doi.org/10.1023/A: 1006859511756

Dolan, P., T. Peasgood and M. White 2008. Do we really know what makes us happy? A review of the economic literature on the factors associated with subjective well-being. Journal of Economic Psychology 29(1): 94-122. https://doi.org/10.1016/j. joep.2007.09.001

Easterlin, R. 2005. A puzzle for adaptive theory. Journal of Economic Behavior and Organization 56(4): 513-521. https://doi.org/10.1016/j.jebo.2004.03.003

Elsinga, M. and J. Hoekstra 2005. Homeownership and housing satisfaction. Journal of Housing and the Built Environment 20: 401-424. https://doi.org/10.1007/s10901-0059023-4

Eurostat. 2019. Living conditions - cities and greater cities. Retrieved from http://appsso. eurostat.ec.europa.eu/nui/show.do?dataset=urb_clivcon\&lang=en, accessed on 23 May 2019

Fairlie, R. W. 2005. An extension of the Blinder-Oaxaca decomposition technique to logit and probit models. Journal of Economic and Social Measurement 30(4): 305-316. https: //doi.org/10.3233/JEM-2005-0259

Fasang, A. E., J. Huinink and M. Pollmann-Schult 2016. Aktuelle Entwicklungen in der deutschen Familiensoziologie: Theorien, Daten, Methoden. Zeitschrift für Familienforschung 28(1): 112-143. https://doi.org/10.3224/zff.v28i1.22923

Frey, B. and A. Stutzer 2002. Happiness and economics: How the economy and institutions affect human well-being. Oxford: Princeton University Press.

Friedlander, D., B. Okun and S. Segal 1999. The demographic transition then and now: processes, perspectives and analyses. Journal of Family History 24(4): 493-533. https: //doi.org/10.1177/036319909902400406

Fritsch, N.-S., R. Verwiebe and C. Liebhart 2019. Arbeit und Berufe in Österreich: Veränderte Einstellungsmuster im Kontext eines tief greifenden Strukturwandels. In Sozialstruktur und Wertewandel in Österreich, eds J. Bacher, A. Grausgruber, M. Haller, F. Höllinger, D. Prandner and R. Verwiebe, 333-385. Wiesbaden: VS Verlag für Sozialwissenschaften. https://doi.org/10.1007/978-3-658-21081-6_15

Fritsch, N.-S., R. Verwiebe and B. Liedl 2019. Declining gender differences in low-wage employment in Germany, Austria and Switzerland. Comparative Sociology 18(4): 449488. https://doi.org/10.1163/15691330-12341507 
Ge, J. and K. Hokao 2006. Research on residential lifestyles in Japanese cities from the viewpoints of residential preference, residential choice and residential satisfaction. Landscape and Urban Planing 78(3): 165-178. https://doi.org/10.1016/j.landurbplan. 2005.07.004

Hall, R. and P. Ogden 2003. The rise of living alone in Inner London: Trends among the population of working age. Environment and Planning 35(5): 871-888. https://doi.org/10. 1068/a3549

Hall, R., P. Ogden and C. Hill 1997. The pattern and structure of one-person households in England and Wales and France. International Journal of Population Geography 3(2): 161-181. https://doi.org/10.1002/(SICI)1099-1220(199706)3:2<161::AIDIJPG64>3.0.CO;2-2

Haller, M. and M. Hadler 2006. How social relations and structures can produce happiness and unhappiness: An international comparative analysis. Social Indicators Research 75(2): 169-216. https://doi.org/10.1007/s11205-004-6297-y

Heintzman, P. 2020. Empirical research on leisure and spiritual well-being: Conceptualisation, measurement and findings. Leisure Studies 39(1): 146-155. https://doi.org/10.1080/ 02614367.2019.1684981

Hejj, A. 1997. Jung, ledig sucht: die Welt der Singles. Journal of Family Research 9(2): 26-47. Retrieved from https://nbn-resolving.org/urn:nbn:de:0168-ssoar-291674

Helliwell, J. 2003. How's life? Combining individual and national variables explain subjective well-being. Economic Modelling 20(2): 331-360. https://doi.org/10.1016/S0264-9993(02) 00057-3

Hertel, J., A. Schütz, B. M. DePaulo, W. L. Morris and T. S. Stucke 2007. She's single, so what? Journal of Family Research 19(2): 139-158. https://doi.org/10.20377/jfr-301

Hettlage, R. 2000. Individualization, pluralization, post-familiarization: dramatic or dramatized upheavals in the modernization process in the family? Journal of Family Research 12(1): 72-97. Retrieved from https://nbn-resolving.org/urn:nbn:de:0168-ssoar-291123

Hochschild, A. R. 2001. The time bind. When work becomes home and home becomes work 2nd ed., New York: Holt Paperbacks.

Hogan, M., K. Leyden, R. Conway, A. Goldberg, D. Walsh and P. McKenna-Plumley 2016. Happiness and health across the lifespan in five major cities: The impact of place and government performance. Social Science $\mathcal{E}$ Medicine 162: 168-176. https://doi.org/10. 1016/j.socscimed.2016.06.030

Hradil, S. 1995. Die Single-Gesellschaft. München: C.H. Beck.

Huinink. 1995. Warum noch Familie? Zur Attraktivität von Partnerschaft und Elternschaft in unserer Gesellschaft. Frankfurt/Main: Campus.

Jann, B. 2006. Stata module to generate nonlinear decomposition of binary outcome differentials. Boston College Department of Economics: Statistical Software Components. Retrieved from http://ideas.repec.org/c/boc/bocode/s456727.html

Kahn, M. 1995. A revealed preference approach to ranking city quality of life. Journal of Urban Economics 38(2): 221-235. https://doi.org/10.1006/juec.1995.1030

Kamp Dush, C. and P. Amato 2005. Consequences of relationship status and quality for subjective well-being. Journal of Social and Personal Relationships 22(5): 607-627. https://doi.org/10.1177/0265407505056438 
Karlson, K. B., A. Holm and R. Breen 2012. Comparing regression coefficients between samesample nested models using logit and probit: A new method. Sociological Methodology 42(1): 286-313. https://doi.org/10.1177/0081175012444861

Klinenberg, E. 2012. Going solo. The extraordinary rise and surprising appeal of living alone. New York: The Penguin Press.

Krekel, C., J. Kolbe and H. Wüstemann 2016. The greener, the happier? The effect of urban land use on residential well-being. Ecological Economics 121: 117-127. https://doi.org/10.1016/j.ecolecon.2015.11.005

Kuijsten, A. 1995. Recent trends in household and family structures in Europe: An overview. In Household demography and household modelling, eds E. Van Imhoff, A. Kuijsten, P. Hooimeijer and L. Van Wissen, 53-84. New York and London: Plenum Press. https://doi.org/10.1007/978-1-4757-5424-7_3

Lawton, P. and J. Cohen 1974. The generality of housing impact on the well-being of older people. Journal of Gerontology 29(2): 194-204. https://doi.org/10.1093/geronj/29.2.194

Layard, R. 2005. Happiness: Lessons from a new science. New York, London: Penguin Books.

Lee, G., K. Seccombe and C. Sheehan 1991. Marital status and personal happiness: An anlysis of trend data. Journal of Marriage and the Family 53(4): 839-844. https://doi.org/ $10.2307 / 352991$

Lee, Y. and V. Bhargava 2004. Leisure time: Do married and single individuals spend it differently? Journal of Family and Consumer Sciences 32(2): 254-274. https://doi.org/10. 1177/1077727X03261631

Lesthaeghe, R. 2010. The unfolding story of the second demographic transition. Population and Development Review 36(2): 211-251. https://doi.org/10.1111/j.1728-4457.2010. 00328.x

Luhmann, M. and L. Hawkley 2016. Age differences in loneliness from late adolescence to oldest old age. Developmental Psychology 52(6): 943-959. https://doi.org/10.1037/ $\operatorname{dev} 0000117$

Maldonado, L. and R. Nieuwenhuis 2015. Family policies and single parent poverty in 18 OECD countries, 1978-2008. Community, Work E Family 18(4): 395-415. https: //doi.org/10.1080/13668803.2015.1080661

Marans, R. 2012. Quality of urban life studies: An overview and implications for environmentbehaviour research. Procedia - Social and Behavioral Sciences 35: 9-22. https://doi.org/ 10.1016/j.sbspro.2012.02.058

Marans, R. and R. Stimson (eds). 2011. Investigating quality of urban life. Dodrecht: Springer. https://doi.org/10.1007/978-94-007-1742-8

Mastekaasa, A. 1994. Marital status, distress, and well-being: An international comparison. Journal of Comparative Family Studies 25(2): 183-205. https://doi.org/10.3138/jcfs. 25.2.183

Matthews, R. A., R. E. Del Priore, L. K. Acitelli and J. L. Barnes-Farrell 2006. Work-torelationship conflict: Crossover effects in dual-earner couples. Journal of Occupational Health Psychology 11(3): 228-240. https://doi.org/10.1037/1076-8998.11.3.228

Matysiak, A., L. Mencarini and D. Vignoli 2016. Work-family conflict moderates the relationship between childbearing and subjective well-being. European Journal of Population 32(3): 355-379. https://doi.org/10.1007/s10680-016-9390-4 
Mood, C. 2010. Logistic regression: Why we cannot do what we think we can do, and what we can do about it. European Sociological Review 26(1): 67-82. https://doi.org/10.1093/ esr/jcp006

Morgan, S. P. and R. B. King 2001. Why have children in the 21st century? Biological predisposition, social coercion, rational choice. European Journal of Population 17(1): 3-20. https://doi.org/10.1023/A:1010784028474

Nieboer, A. and S. Lindenberg 2002. Substitution, buffers and subjective well-being: A hierarchical approach. In The universality of subjective well-being indicators, eds E. Gullone and R. A. Cummins, 175-189. Dordrecht: Kluwer Academic Publishers. https://doi.org//10.1007/978-94-010-0271-4_10

Ogden, P. and R. Hall 2000. Households, reurbanisation and the rise of living alone in the principal french cities, 1975-90. Urban Studies 37(2): 367-390. https://doi.org/10.1080/ 0042098002230

Okulicz-Kozaryn, A. 2013. City life: Rankings (livability) versus perceptions (statisfaction). Social Indicators Research 110(2): 433-451. https://doi.org/10.1007/s11205-011-9939-x

Ormel, J., S. Lindenberg, N. Steverink and L. Verbrugge 1999. Subjective well-being and social production functions. Social Indicators Research 46(1): 61-90. https://doi.org/10. 1023/A:1006907811502

Poortman, A.-R. and A. Liefbroer 2010. Singles' relational attitudes in a time of individualization. Social Science Research 39(6): 938-949. https://doi.org/10.1016/j. ssresearch.2010.03.012

Riederer, B. 2018. Elternschaft und Wohlbefinden. Wiesbaden: Springer VS. https://doi.org/ 10.1007/978-3-658-22561-2

Riederer, B., M. Mynarska, M. Winkler-Dworak, T. Fent, B. Rengs and D. Philipov 2017. Vulnerability and the future of families with children in Europe. Nine questions and corresponding answers. Vienna: Austrian Academy of Sciences. Retrieved from: https://www.oeaw.ac.at/fileadmin/subsites/Institute/VID/PDF/ Publications/Schriftenreihe/VID_Schriftenreihe_23.pdf.

Salvatori, A. and T. Manfredi 2019. Job polarisation and the middle class: New evidence on the changing relationship between skill levels and household income levels from 18 OECD countries. Paris: OECD Social, Employment and Migration Working Papers N. 232. https://doi.org/10.1787/1815199X

Schoon, I., L. Hansson and K. Salmela-Aro 2005. Combining work and family life. European Psychologist 10(2005): 309-319. https://doi.org/10.1027/1016-9040.10.4.309

Shapiro, A. and C. L. Keyes 2008. Marital status and social well-being: Are the married always better off? Social Indicators Research 88(2): 329-346. https://doi.org/10.1007/ s11205-007-9194-3

Soons, J. and M. Kalmijn 2009. Is marriage more than cohabitation? Well-being differences in 30 European Countries. Journal of Marriage and Family 71(5): 1141-1157. https://doi.org/10.1111/j.1741-3737.2009.00660.x

Soons, J. and A. Liefbroer 2008. Together is better? Effects of relationship status and resources on young adults' well-being. Journal of Social and Personal Relationships 25(4): 603-624. https://doi.org/10.1177/0265407508093789 
Statistics Austria 2020. Lebensformen 1971-2019. Retrieved from https: //www.statistik.at/web_de/statistiken/menschen_und_gesellschaft/bevoelkerung/ haushalte_familien_lebensformen/lebensformen/index.html, accessed on 21 April 2020.

Statistik Journal Wien 2016. Entwicklung der Privathaushalte in Wien und den 23 Wiener Gemeindebezirke. Wien: Statistik Austria.

Teitzer, R., N.-S. Fritsch and R. Verwiebe 2014. Arbeitsmarktflexibilisierung und Niedriglohnbeschäftigung: Deutschland und Österreich im Vergleich. WSI-Mitteilungen 67(4): 257-266. https://doi.org/10.5771/0342-300X-2014-4-257

Tov, W. and E. Diener 2007. Culture and subjective well-being. In Handbook of cultural psychology, eds S. Kitayama and D. Cohen, 691-713. New York: Guilford Press. https://doi.org/10.1007/978-90-481-2352-0_2

Van de Kaa, D. J. 1987. Europe's second demographic transition. Population Bulletin 42(1): $1-59$.

Vanassche, S., G. Swicegood and K. Matthijs 2013. Marriage and children as a key to happiness? Cross-national differences in the effects of marital status and children on well-being. Journal of Happiness Studies 14(2): 501-524. https://doi.org/10.1007/s10902012-9340-8

Vaughan-Whitehead, D., R. Vazquez-Alvarez and N. Maitre 2016. Is the world of work behind middle-class erosion? In Europe's disappearing middle class, ed D. Vaugan-Whitehead, 1-61. Cheltenham: Edward Elgar Publishing.

Veenhoven, R. 2000. The four qualities of life. Journal of Happiness Studies 1(1): 1-39. https://doi.org/10.1023/A:1010072010360

Veenhoven, R. 2007. Quality-of-life research. In 21st century sociology. A reference handbook, eds C. D. Bryant and D. L. Peck, 54-62. Thousand Oak: Sage.

Vera-Toscano, E. and V. Ateca-Amestoy 2008. The relevance of social interactions on housing satisfaction. Social Indicators Research 86: 257-274. https://doi.org/10.1007/s11205-0079107-5

Verwiebe, R. 2014. Die Auflösung der Mittelschicht und wachsende Armut in Deutschland. Sozialer Fortschritt 63(12): 293-300.

Verwiebe, R. and N.-S. Fritsch 2011. Working Poor in Österreich. In Armut in Österreich, ed R. Verwiebe, 149-167. Vienna: Braumüller Verlag.

Verwiebe, R., T. Troger, L. Wiesböck, R. Teitzer and N.-S. Fritsch 2013. GINI Country Report: Growing inequalities and their impacts in Austria. Amsterdam: AIAS Amsterdam Insitute for Advanced Labour Studies. Retrieved from https://EconPapers.repec.org/RePEc:aia: ginicr:austria

Weziak-Bialowolska, D. 2016. Quality of life in cities - Empirical evidence in comparative European perspective. Cities 58: 87-96. https://doi.org/10.1016/j.cities.2016.05.016

Zartler, U., M. Beham, I. Kromer, H. Leitgöb, C. Weber and P. Friedl 2011. Alleinerziehende in Österreich: Lebensbedingungen und Armutsrisiken. Wien: ÖGB-Verlag/BMASK. Retrieved from https://nbn-resolving.org/urn:nbn:de:0168-ssoar-412644

Zenker, S., S. Petersen and A. Aholt 2013. The Citizen Satisfaction Index (CSI): Evidence for a four basic factor model in a German sample. Cities 31: 156-164. https://doi.org/10. 1016/j.cities.2012.02.006 


\section{Appendix}

Table A.1:

Subjective well-being among single households and the total population 1995-2018 (mean satisfaction and \% very satisfied or satisfied)

\begin{tabular}{|c|c|c|c|c|c|}
\hline \multirow[b]{2}{*}{ Subjective well-being (SWB) } & & \multicolumn{2}{|c|}{ Single households } & \multicolumn{2}{|c|}{ Population } \\
\hline & & $\mathbf{m}$ & $\%$ & $\mathbf{m}$ & $\%$ \\
\hline \multirow[t]{5}{*}{ Overall life satisfaction } & 1995 & 1.93 & 78 & 1.78 & 83 \\
\hline & 2003 & 1.96 & 79 & 1.83 & 84 \\
\hline & 2008 & 1.94 & 79 & 1.79 & 84 \\
\hline & 2013 & 1.90 & 80 & 1.77 & 85 \\
\hline & 2018 & 2.01 & 74 & 1.88 & 79 \\
\hline \multicolumn{6}{|l|}{ Domains of material WB } \\
\hline \multirow[t]{5}{*}{ Housing } & 1995 & 1.93 & 78 & 2.07 & 72 \\
\hline & 2003 & 1.86 & 80 & 1.89 & 79 \\
\hline & 2008 & 1.83 & 78 & 1.77 & 82 \\
\hline & 2013 & 1.81 & 81 & 1.79 & 81 \\
\hline & 2018 & 1.84 & 78 & 1.88 & 76 \\
\hline \multirow[t]{4}{*}{ Finances } & 2003 & 2.40 & 62 & 2.31 & 64 \\
\hline & 2008 & 2.24 & 65 & 2.16 & 67 \\
\hline & 2013 & 2.26 & 65 & 2.14 & 68 \\
\hline & 2018 & 2.38 & 60 & 2.26 & 64 \\
\hline \multicolumn{6}{|l|}{ Domains of social WB } \\
\hline \multirow[t]{5}{*}{ Family } & 1995 & 1.96 & 73 & 1.59 & 86 \\
\hline & 2003 & 2.00 & 75 & 1.68 & 86 \\
\hline & 2008 & 1.94 & 76 & 1.61 & 87 \\
\hline & 2013 & 1.83 & 78 & 1.56 & 87 \\
\hline & 2018 & 2.03 & 73 & 1.75 & 81 \\
\hline \multirow[t]{5}{*}{ Social contacts } & 1995 & 1.65 & 87 & 1.55 & 90 \\
\hline & 2003 & 1.73 & 86 & 1.63 & 89 \\
\hline & 2008 & 1.70 & 84 & 1.58 & 88 \\
\hline & 2013 & 1.61 & 87 & 1.55 & 89 \\
\hline & 2018 & 1.84 & 79 & 1.77 & 81 \\
\hline
\end{tabular}

Continued 
Table A.1:

Continued

\begin{tabular}{|c|c|c|c|c|c|}
\hline \multirow[b]{2}{*}{ Subjective well-being (SWB) } & & \multicolumn{2}{|c|}{ Single households } & \multicolumn{2}{|c|}{ Population } \\
\hline & & $\mathbf{m}$ & $\%$ & $\mathbf{m}$ & $\%$ \\
\hline \multicolumn{6}{|l|}{ Cross-sectional domains } \\
\hline \multirow[t]{4}{*}{ Main activity } & 2003 & 1.91 & 80 & 1.86 & 81 \\
\hline & 2008 & 1.86 & 80 & 1.81 & 82 \\
\hline & 2013 & 1.84 & 80 & 1.76 & 84 \\
\hline & 2018 & 2.00 & 74 & 1.95 & 77 \\
\hline \multirow[t]{5}{*}{ Leisure time } & 1995 & 1.93 & 77 & 1.91 & 76 \\
\hline & 2003 & 1.99 & 76 & 1.97 & 77 \\
\hline & 2008 & 1.97 & 77 & 1.92 & 77 \\
\hline & 2013 & 1.87 & 78 & 1.88 & 79 \\
\hline & 2018 & 1.93 & 75 & 2.11 & 68 \\
\hline$N(\min -\max )$ & & \multicolumn{2}{|c|}{$1,685-2,533$} & \multicolumn{2}{|c|}{ 7,933-8,693 } \\
\hline
\end{tabular}

Note: Satisfaction scales range from 1 (very satisfied) to 5 (not satisfied at all).

Source: Viennese Quality of Life Surveys (1995-2018); $N=41,920$; own weighted calculations.

Table A.2:

Characteristics of persons in single households and in other household types 2018 (\%)

\begin{tabular}{|c|c|c|c|c|c|c|}
\hline $\begin{array}{l}\text { Living } \\
\text { arrangement: }\end{array}$ & $\begin{array}{c}\text { Single } \\
\text { households }\end{array}$ & $\begin{array}{l}\text { Two adults } \\
\text { without } \\
\text { children }\end{array}$ & $\begin{array}{l}\text { Two adults } \\
\text { with } \\
\text { children } \\
\text { below age } 15\end{array}$ & $\begin{array}{c}\text { Single } \\
\text { parents }\end{array}$ & $\begin{array}{c}\text { Other } \\
\text { households }\end{array}$ & $\begin{array}{l}\text { Total } \\
\text { sample }\end{array}$ \\
\hline \multicolumn{7}{|l|}{ Confounders } \\
\hline \multicolumn{7}{|l|}{ Relationship status: } \\
\hline Partner & 28 & 67 & 80 & 40 & 51 & 53 \\
\hline Married & 3 & 62 & 75 & 15 & 30 & 38 \\
\hline Divorced/widowed & 40 & 6 & 3 & 39 & 15 & 18 \\
\hline Gender: female & 58 & 54 & 53 & 76 & 53 & 55 \\
\hline \multicolumn{7}{|l|}{ Age: } \\
\hline 15 to 29 yrs. & 15 & 15 & 11 & 18 & 48 & 24 \\
\hline 30 to 44 yrs. & 22 & 20 & 60 & 51 & 13 & 25 \\
\hline 45 to 59 yrs. & 27 & 29 & 27 & 30 & 28 & 28 \\
\hline 60 to 99 yrs. & 36 & 36 & 2 & 1 & 11 & 23 \\
\hline
\end{tabular}

\section{Continued}


Table A.2:

Continued

\begin{tabular}{|c|c|c|c|c|c|c|}
\hline $\begin{array}{l}\text { Living } \\
\text { arrangement: }\end{array}$ & $\begin{array}{c}\text { Single } \\
\text { households }\end{array}$ & $\begin{array}{l}\text { Two adults } \\
\text { without } \\
\text { children }\end{array}$ & $\begin{array}{c}\text { Two adults } \\
\text { with } \\
\text { children } \\
\text { below age } 15\end{array}$ & $\begin{array}{c}\text { Single } \\
\text { parents }\end{array}$ & $\begin{array}{c}\text { Other } \\
\text { households }\end{array}$ & $\begin{array}{c}\text { Total } \\
\text { sample }\end{array}$ \\
\hline \multicolumn{7}{|l|}{ Subjective health: } \\
\hline Very good & 25 & 29 & 36 & 31 & 33 & 30 \\
\hline Good & 45 & 50 & 45 & 40 & 42 & 46 \\
\hline Moderate & 24 & 18 & 17 & 23 & 20 & 20 \\
\hline Worse & 6 & 3 & 2 & 7 & 5 & 5 \\
\hline \multicolumn{7}{|l|}{ Employment: } \\
\hline Unemployed & 7 & 3 & 5 & 13 & 7 & 6 \\
\hline In employment & 51 & 57 & 80 & 70 & 51 & 57 \\
\hline Other & 42 & 40 & 15 & 17 & 42 & 37 \\
\hline $\begin{array}{l}\text { Immigrant background } \\
\text { Mediators }\end{array}$ & 27 & 26 & 42 & 42 & 49 & 35 \\
\hline $\begin{array}{l}\text { Equivalised household } \\
\text { Income: lower } 25 \%\end{array}$ & 28 & 11 & 25 & 49 & 39 & 26 \\
\hline 26 to $50 \%$ & 24 & 17 & 30 & 31 & 26 & 24 \\
\hline 51 to $75 \%$ & 26 & 32 & 25 & 13 & 20 & 26 \\
\hline 76 to $100 \%$ & 22 & 39 & 19 & 7 & 15 & 24 \\
\hline $\begin{array}{l}\text { Square meters } \\
\text { Per household } \\
\text { Member: up to } 25 \mathrm{~m}^{2}\end{array}$ & 1 & 10 & 52 & 38 & 35 & 21 \\
\hline 26 to $35 \mathrm{~m}^{2}$ & 8 & 27 & 33 & 33 & 32 & 24 \\
\hline 36 to $45 \mathrm{~m}^{2}$ & 14 & 28 & 9 & 18 & 18 & 18 \\
\hline 46 to $70 \mathrm{~m}^{2}$ & 42 & 27 & 5 & 8 & 11 & 24 \\
\hline More than $70 \mathrm{~m}^{2}$ & 35 & 7 & 1 & 2 & 4 & 13 \\
\hline $\begin{array}{l}\text { Living environment: } \\
\text { No impairments }\end{array}$ & 36 & 34 & 33 & 34 & 32 & 34 \\
\hline Almost no impairments & 33 & 33 & 33 & 27 & 30 & 32 \\
\hline Rarely impairments & 18 & 20 & 21 & 18 & 20 & 19 \\
\hline Some to major impairments & 13 & 13 & 14 & 21 & 17 & 15 \\
\hline
\end{tabular}

Note: The quality of the living environment refers to the absence of problems with quality of air, water supply, road cleaning and waste disposal.

Source: Viennese Quality of Life Survey (2018); $N=8.051$; own unweighted calculations. 
Table A.3:

Differences in overall life satisfaction (\% very satisfied or satisfied) of persons from single households and other household types 2003 and 2018 (AMEs)

\begin{tabular}{|c|c|c|c|c|c|}
\hline Overall life satisfaction & $\mathrm{A} 1(=\mathrm{M1})$ & A2 & A3 & A4 & A5 \\
\hline \multicolumn{6}{|l|}{ Year 2003} \\
\hline \multicolumn{6}{|l|}{ Single households } \\
\hline Two adults without children & $.10^{* * *}$ & $.07^{* * * \mathrm{~d}}$ & $.09^{* * * \mathrm{c}}$ & $.05^{* * \mathrm{~b}}$ & $.02^{\mathrm{a}}$ \\
\hline $\begin{array}{l}\text { Two adults with } \\
\text { children below age } 15\end{array}$ & $.05^{* * *}$ & $.04^{*}$ & $.09^{* * * a}$ & $.05^{* *}$ & .01 \\
\hline Single parents & $-.04^{(*)}$ & $-.02^{\mathrm{d}}$ & $.01^{\mathrm{a}}$ & $.01^{\mathrm{a}}$ & $.00^{\mathrm{c}}$ \\
\hline Other households & $.04^{* *}$ & $.03^{(*)}$ & $.06^{* * *}$ & .03 & .00 \\
\hline Cragg \& Uhler's $\mathrm{R}^{2}$ & 2.7 & 17.6 & 11.7 & 22.3 & 45.2 \\
\hline \multicolumn{6}{|l|}{ Year 2018} \\
\hline \multicolumn{6}{|l|}{ Single households } \\
\hline Two adults without children & $.11^{* * *}$ & $.04^{* * * \mathrm{a}}$ & $.11^{* * *}$ & $.05^{* * * a}$ & $.01^{\mathrm{a}}$ \\
\hline $\begin{array}{l}\text { Two adults with } \\
\text { children below age } 15\end{array}$ & $.07^{* * *}$ & $.03^{(*) \mathrm{c}}$ & $.13^{* * * a}$ & $.06^{* * *}$ & $.02^{\mathrm{d}}$ \\
\hline Single parents & $-.07^{*}$ & $-.01^{\mathrm{a}}$ & $.05^{(*) \mathrm{a}}$ & $.04^{\mathrm{a}}$ & $.01^{\mathrm{b}}$ \\
\hline Other households & .01 & $.02 *$ & $.10^{* * * a}$ & $.05^{* * * \mathrm{c}}$ & .01 \\
\hline Cragg \& Uhler's R ${ }^{2}$ & 2.5 & 26.9 & 19.0 & 33.5 & 54.8 \\
\hline Confounders & & incl. & & incl. & incl. \\
\hline Mediators & & & incl. & incl. & incl. \\
\hline Domains of material WB & & & & & incl. \\
\hline Domains of social WB & & & & & incl. \\
\hline Cross-sectional domains & & & & & incl. \\
\hline Differences between models & & $\operatorname{lr} \mathrm{chi}^{2}$ & $\operatorname{lr} \mathrm{chi}^{2}$ & $\operatorname{lr} \mathrm{chi}^{2}$ & $\operatorname{lr} \mathrm{chi}^{2}$ \\
\hline Tests vs. A1: Year 2003 & ref. & $711^{* * *}$ & $423^{* * *}$ & & \\
\hline Year 2018 & ref. & $1375^{* * *}$ & $901^{* * *}$ & & \\
\hline Tests vs. A2: Year 2003 & & ref. & & $239^{* * *}$ & \\
\hline Year 2018 & & ref. & & $414^{* * *}$ & \\
\hline Tests vs. A3: Year 2003 & & & ref. & $528^{* * *}$ & \\
\hline Year 2018 & & & ref. & $887^{* * *}$ & \\
\hline Tests vs. A4: Year 2003 & & & & ref. & $1280^{* * *}$ \\
\hline Year 2018 & & & & ref. & $1513^{* * *}$ \\
\hline
\end{tabular}

Note: The table gives average marginal effects (AMEs). Confounders comprise the following characteristics: gender (male/female), partnership (no/yes), married (no/yes), divorced/widowed (no/yes), age (4 categories), subjective health (4 categories), unemployed (no/yes), in employment (no/yes), and immigrant background (no/yes). Mediators include household income (4 categories), square meters per person in household (5 categories), quality of living environment (index incl. quality of air, water supply, road cleaning, waste disposal; 4 categories). Life domains satisfaction measures refer to housing and financial situation (domains of material well-being), family life and social contacts (domains of social well-being), and main activity and leisure time (cross-sectional domains). Tests referring to coefficients: (a) Tests on differences compared to single households: ${ }^{* * *} p \leq .001,{ }^{* *} p \leq .01,{ }^{*} p \leq .05,{ }^{(*)} p \leq .06$; (b) tests on differences compared to A1: ${ }^{\mathrm{a}} p \leq .001,{ }^{\mathrm{b}} p \leq .01,{ }^{\mathrm{c}} p \leq .05,{ }^{\mathrm{d}} p \leq .06$.

Source: Viennese Quality of Life Surveys $(2003,2018) ; N_{2003}=7.866 ; N_{2018}=8.051$; own unweighted calculations. 
Open Access This article is published under the terms of the Creative Commons Attribution 4.0 International License (https://creativecommons.org/licenses/by/4.0/) that allows the sharing, use and adaptation in any medium, provided that the user gives appropriate credit, provides a link to the license, and indicates if changes were made. 